\title{
Artichoke extracts in cancer therapy: do the extraction conditions affect the anticancer activity?
}

\author{
Heba H. Sokkar', Ahmed S. Abo Dena ${ }^{2,3^{*}}$ (D, Noha Ahmed Mahana ${ }^{1}$ and Abeer Badr ${ }^{1}$
}

\begin{abstract}
Background: Artichoke is an edible plant that is grown in the Mediterranean region and is known for its antimicrobial, antifungal, antibacterial, antioxidant and anticancer activities. Different artichoke extraction methods can impressively affect the nature as well as the yield of the extracted components.

Main body: The different methods of artichoke extraction and the influence of the extraction conditions on the extraction efficiency are summarized herein. In addition, cancer causalities and hallmarks together with the molecular mechanisms of artichoke active molecules in cancer treatment are also discussed. Moreover, a short background is given on the common types of cancer that can be treated with artichoke extracts as well as their pathogenesis. A brief discussion of the previous works devoted to the application of artichoke extracts in the treatment of these cancers is also given.

Conclusion: This review article covers the extraction methods, composition, utilization and applications of artichoke extracts in the treatment of different cancers.
\end{abstract}

Keywords: Anticancer, Artichoke, Solvent extraction, Apoptosis, Polyphenols

\section{Background}

Cancer is one of the most popular fatal diseases with an overall estimate of $1,735,350$ cases for 2018 which is equivalent to more than 4700 new cancer diagnoses per day. The risk of cancer during the lifetime of humans is $39.7 \%$ for men and $37.6 \%$ for women which is a little more than 1 in 3 according to the American Cancer Society reports. Body cells are normally growing in response to tightly controlled cell-cycle signalling pathway $[1,2]$ by which cells are dividing, connected to each other, proliferating and even dying when they are no longer needed. Cancer cells are normal body cells that lose the ability to control their division and growth

\footnotetext{
* Correspondence: ahmed_said5899@yahoo.com

${ }^{2}$ Pharmaceutical Chemistry Department, National Organization for Drug

Control and Research (NODCAR), Giza, Egypt

${ }^{3}$ Faculty of Oral and Dental Medicine, Future University in Egypt (FUE), New Cairo, Egypt

Full list of author information is available at the end of the article
}

which may occur due to many reasons known as "cancer hallmarks". These hallmarks include alterations in the proliferation signalling pathways' compartments such as receptors, ligands and cytosolic signalling molecules. In addition, altered stress responses represented by DNA damage, hypoxia and excessive signalling, metastasis, and change in shape are considered common hallmarks of cancer. Moreover, in order to support cancer cells with oxygen and nutrients, angiogenesis (the process of blood vessel formation from pre-existing ones) is highly required for the adaptation and sustainability of cancerous tissues. Usually, these abnormal vessels tend to be leaky leading to cancer metastasis to other body tissues. Cancer cells are also able to escape from the immune system via two well-known mechanisms, immuneediting and immune surveillance [3].

Many trials have been reported on the treatment of cancers using surgical, chemo-, radio-, immuno and/or hormonal therapies, either by using only one treatment 
plan or by combination of two or more different plans. Unfortunately, no one of these therapies was as efficient as thought, and in addition, each of them has its undesirable side effects such as weight and hair loss, hormonal disturbances, fatigue, nausea, vomiting, anaemia and immunodeficiency. A new trend in cancer therapy has emerged depending on plant-derived products as anticancer agents due to their availability, low production costs and high efficiency with almost no side effects when compared to synthetic drugs.

Artichoke is a very popular plant widely cultivated in the Mediterranean area due to its nutritional and medicinal benefits. It belongs to the kingdom Plantae, class Magnoliopsida, family Asteraceae and genus Cynara. The plant body is composed of three main parts (Fig. 1): (i) the head or capital which is mainly composed of immature flowers and represents about $30-40 \%$ of the plant fresh weight (FW), (ii) the heart which is mainly composed of the bracts, receptacles and the inner leaves and it represents $35-40 \%$ of the FW and (iii) the stroke [4-6]. Artichoke-derived molecules are well known for their antifungal, antibacterial, antioxidant and anticancer activities $[7,8]$. The extracts of the plant leaves and the edible part are thought to have anticancer activity against various types of cancer owing to the presence of some components including polyphenols, flavonoids,

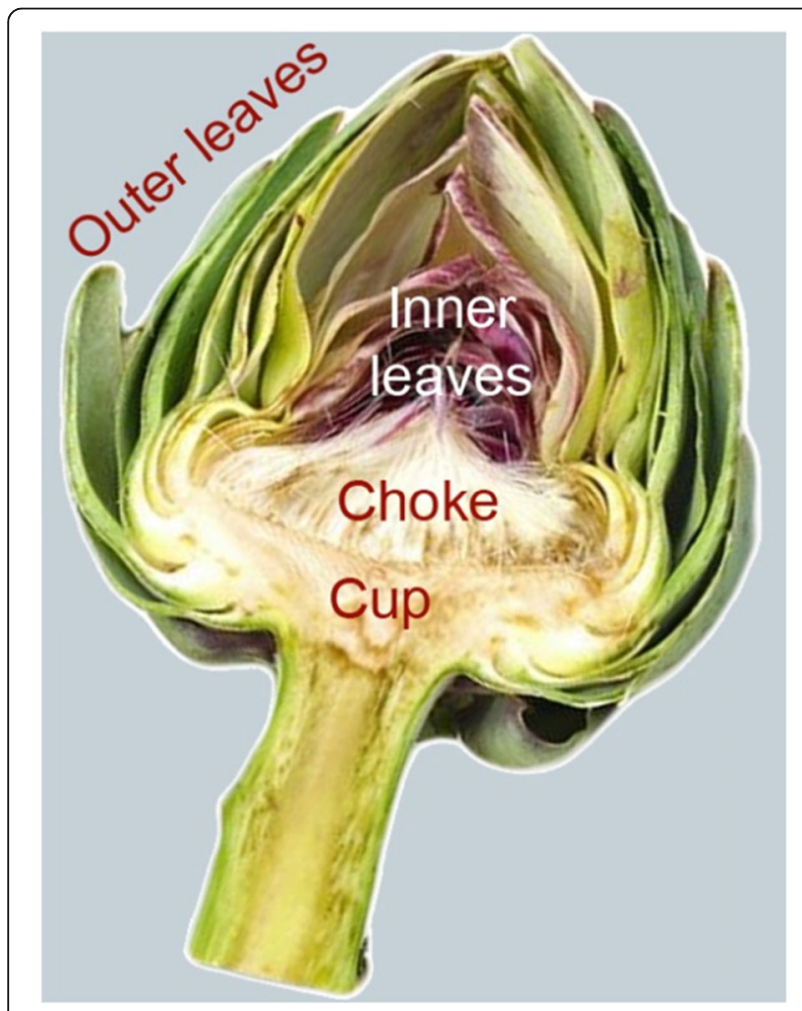

Fig. 1 Longitudinal section in artichoke showing its main anatomical parts fatty acids and inulin which are proved to be cytotoxic to different cancer cells such as skin, breast, cervical, leukaemia and hepatocellular carcinoma. The anticancer activity of these extracts differs according to the extraction methods, the types of solvents used in the extraction process and the applied conditions which have a significant influence on the yield of the anticancer components. This review summarises the previously reported extraction methods and the effects of extraction conditions on the anticancer activity of different artichoke extracts as well as the applications of artichoke extracts in the treatment of various cancer types. In addition, we have summarized cancer causalities, properties and the molecular mechanisms of common plant-derived compounds that act as anticancer agents inside the cancer cells.

In this review, a Google Scholar-based search was used to cover the literature of the last decade (2010-2019). Fig. 2 depicts the increase of number of publications on artichoke extract and the polyphenols in this period.

\section{Main text \\ Artichoke as an anticancer agent}

In this section, the types of cancer that can be treated with artichoke extracts (based on previous studies in the literature) are discussed in addition to the most common cancer hallmarks.

\section{Cancer hallmarks}

In order to summarise the role of artichoke plant extracts as antitumor agents, it is necessary to have an idea about causalities of cancers (a.k.a. cancer hallmarks). Hanahan and Weinberg published a very good review article in this issue summarizing all possible biological capabilities acquired during the steps of cancer development [9]. They suggested that six hallmarks constitute a logical framework that explains the remarkable diversity of cancers [10]. These hallmarks include (i) sustaining proliferative signalling, (ii) averting growth suppressors, (iii) resisting cell death, (iv) enabling replicative immortality, (v) inducing angiogenesis and (vi) activating invasion and metastasis. Tumours are more than discrete masses of proliferative cancer cells. Instead, they are complex tissues consisting of various distinct types of cells capable of interacting with one another. Intensive research on cancer production revealed that these six properties are not all the hallmarks that participate in cancer development and sustainability. Indeed, there are other four emerging hallmarks that play a very important role in cancer pathogenesis. These hallmarks are deregulating cellular energetics, genome instability and mutation, thus avoiding immune destruction (via two mechanisms, namely, immune-editing and immune surveillance) and tumour-promoting inflammation [9] (Fig. 

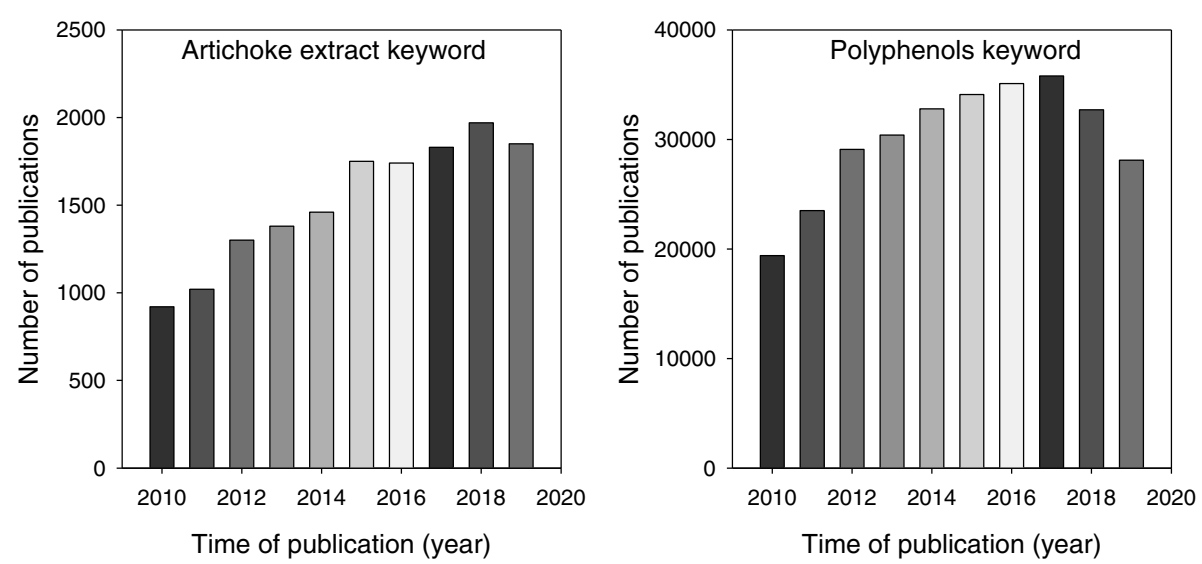

Fig. 2 Number of publications in the period from 2010 to 2019. The data shown in the figure is the Google Scholar search results using the keywords "artichoke extract" and "polyphenols". Patents and citations were excluded from the search results

3). In addition, the release of reactive-oxygen (ROSs) and reactive-nitrogen species (RNSs) is tightly linked to one or more cancer hallmarks. For example, inflamed tissues are capable of producing these chemical species that are famous of their active mutagenic function. Therefore, the presence of ROSs and RNSs can induce serious genome mutations which in turn play a role in deregulation of cellular energetics, activating invasion and metastasis, evading growth suppressors, etc. Consequently, the antitumor activity of a large number of plant-derived molecules is attributed to their ability to battle ROSs and RNSs inside the living cells. Vitamins $\mathrm{C}$ and $\mathrm{E}$ and glutathione (GSH) are common examples for natural antioxidants that help the body to get rid of ROSs and RNSs [11].

Most medicinal, and even edible, plants contain many active substances which act as pharmaceutical agents against various diseases. Generally speaking, polyphenols, flavonoids, sesquiterpene lactones, carotenoids, anthocyanins and xanthones are the most famous groups of plant active substances that have anticancer properties. Artichoke

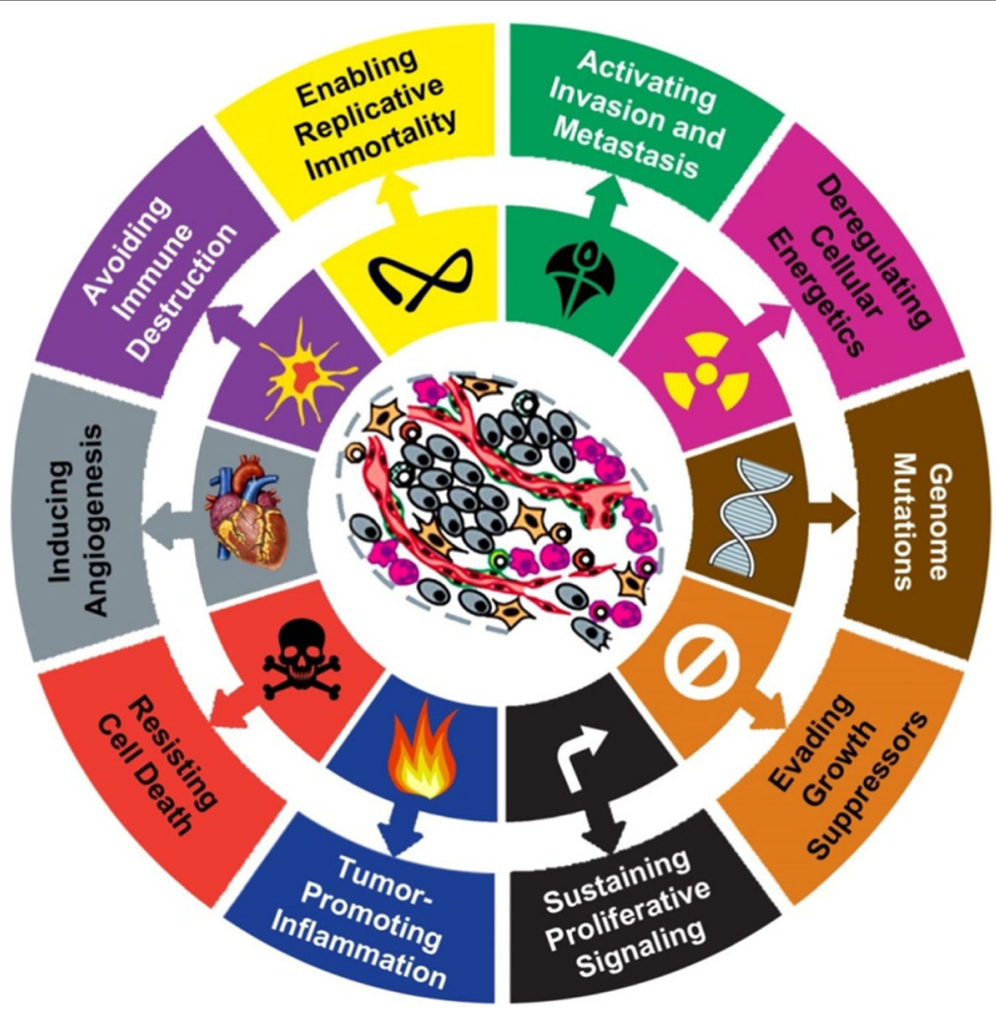

Fig. 3 The 10 cancer hallmarks 
extracts usually contain a large amount of flavonoids and polyphenols [12-15]. The chemical structures of the most common polyphenols obtained from plant extracts are illustrated in Fig. 4.

The molecular mechanism explaining the role of polyphenols as antioxidants will be discussed in one of the following sections. Moreover, we will summarise below the literature devoted to the application of artichoke extracts to the treatment of different cancers. A short account on each cancer type is given at the beginning of each section to enrich the reader's background about the cancer types that were treated with artichoke extracts in the literature.

\section{Breast cancer}

Breast cancer is considered the most spread tumour among women worldwide. In 2017, 250,000 new cases of breast cancer were diagnosed in the USA [17]. It mainly arises due to reproductive factors, family history, body mass index, life style, etc. Breast tumours are categorized by the expression of oestrogen receptor (ER), progesterone receptor (PR) and human epidermal growth factor<smiles>Oc1ccccc1O</smiles><smiles>Oc1cccc(O)c1O</smiles>
Catechol<smiles>CCCC1=C(c2ccccc2)Oc2ccccc2C1</smiles>

Flavanol

(-)-Epicatechin

(EC; 5, 7, 3', 4', 5' = OH, R= H) (-)-Epigallocatechin-3-gallate (EGCG; 5, 7, 3', 4', 5' = OH, $\mathrm{R}=$ gallol)<smiles>O=c1c(O)c(-c2ccccc2)oc2ccccc12</smiles>

Flavonol

Myricetin $\left(3,5,7,3^{\prime}, 4^{\prime}, 5^{\prime}=\mathrm{OH}\right)$ Quercetin $\left(3,5,7,3^{\prime}, 4^{\prime}=\mathrm{OH}\right)$ Morin $\left(3,5,7,2^{\prime}, 4^{\prime}=\mathrm{OH}\right)$<smiles>O=c1ccoc2cccc(O)c12</smiles>

Keto-hydroxyl<smiles>OC1=C(c2ccccc2)Oc2ccccc2C1</smiles>

Chatechins

-Catechin

$\left(5,7,3^{\prime}, 4^{\prime}=\mathrm{OH} ; 2 \mathrm{~S}-3 \mathrm{R}\right)$

(+)-Catechin $\left(5,7,3^{\prime}, 4^{\prime}=\mathrm{OH}\right.$; 2R-3S)<smiles>O=c1cc(-c2ccccc2)oc2ccccc12</smiles>

Flavanone<smiles>O=c1cc(-c2ccccc2)oc2ccccc12</smiles>

Flavone
Taxifolin $\left(3,5,7,3^{\prime}, 4^{\prime}=\mathrm{OH}\right)$ Luteolin $\left(5,7,3,4^{\prime}=\mathrm{OH}\right)$ Hesperidin $\left(5,7,3^{\prime}=\mathrm{OH} ; \quad\right.$ Apigenin $\left(5,7,4^{\prime}=\mathrm{OH}\right)$ $\left.4^{\prime}=\mathrm{OCH}_{3}\right)$<smiles>O=c1c(O)c(-c2ccccc2)oc2ccccc12</smiles>

Anthocyanidin

Cyanidin $\left(3,5,7,3^{\prime}, 4^{\prime}=\mathrm{OH}\right)$

Fig. 4 Basic structures of polyphenols and subclasses of flavonoids [16] 
receptor 2 (HER2). Classification of breast cancers is usually based on the expression of ER, HER2, PR, cytokeratin protein (CK5/6) and epidermal growth factor receptor (EGFR) basal markers. Tumors that lack ER, PR and HER2 receptors are classified as "triple negative" phenotype [18]. This type constitutes $c a .15 \%$ of the breast cancer patients [17].

Breast cancer phenotype that lacks ER, PR and HER2 receptors and expresses CK5/6, CK5 and/or EGFR is known as "core basal" phenotype (CBP) [19]. Some reproductive risk factors (e.g. menarche age and parityrelated variables) are thought to be responsible for the expression of ER and PR in ER- and PR-positive tumours $[20,21]$. CBP tumours are proved to have over representation in breast cancer (BRCA1) gene mutation. BRCA1 as well as BRCA2 are tumor suppressor genes found normally in breast cells separately from each other. Mutations in one of these genes play a crucial role in cancer development in breast tissues. In its early stages, breast cancer is usually non-metastatic, that is why it is considered one of the highly curable diseases when discovered early. However, it is mortal in case of too late detection. Waks and Winer published a valuable review article this year summarizing the recent approaches to systemic and local treatments of the three most common breast cancer phenotypes (HR+/EGFR-, EGFR+ and triple negative) [17]. Breast cancer is one of the diseases that can be effectively treated with artichoke-derived compounds. Herein, we will give some examples for the previously reported work in which artichoke extracts were used for the treatment of breast cancer cell lines.

In one of the studies performed by Demicheli et al., artichoke extracts showed a remarkable cytotoxic activity against different breast cancer cell lines. It was proven that, both aqueous and ethanolic leave extracts have antitumor properties when applied on T-47D and ZR75-1 cell lines. The aqueous extract showed a hermetic associated cytotoxicity against cultivated T-47D and ZR75-1 cell lines when applied for 2 and 3 days with 10$0.63 \%$ concentration range, respectively. Incubation of T-47D cell lines for 2 days with the aqueous extract shows 4 times reduction in cancerous cells with respect to the control, while 3 days incubation leads to a reduction in cell viability which is 5 times higher than that of the control. When incubated with ZR-75-1 cell lines for 2 days, the aqueous extract showed 6 times reduction in cancerous cell viability and 8.5 times reduction when incubated for 3 days with $10-0.31 \%$ concentration compared to the control. The alcoholic leaf extract showed 8 times reduction in T-47D viability when incubated with the cultivated cells for 2 days using a concentration of $10-0.08 \%$ and 9 times reduction when incubated for 3 days with respect to the control. In case of ZR-75-1 cell lines, the alcoholic extract showed 10 and 13 times reduction in the cancerous cell viability with respect to the control when applied with $10-1.25 \%$ concentration range for 2 and 3 days, respectively [22].

Boiled methanolic extract of artichoke heart showed marked cytotoxic activity against MDA-MB 231 cell lines. The treatment of ER-negative MDA-MB231 and BT549, ER-positive, T47D and PR-positive MCF-7 cell lines was achieved by incubating the cells with the methanolic extracts for $24 \mathrm{~h}$. This cytotoxic effect is proved to be related to the presence of phenolic compounds in the methanolic extract such as chlorogenic acid (ChA; 5-O-caffeoylquinic acid), 3,4-dicaffeoylquinic acid (3,4-DCQA), 3,5-DCQA, 1,5-DCQA, and 4,5DCQA. These compounds are analysed using HPLC. The extract was also applied on normal breast epithelial cells (MCF10A) and found to have no toxic effects even at the highest concentrations [23].

\section{Hepatocellular carcinoma}

Hepatocellular carcinoma (HCC) is the primary liver cancer that develops in hepatocytes [24]. HCC became one of the most prevalent malignant hepatic diseases that ranks the sixth in the world malignancies [25]. HCC is usually associated with liver cirrhosis which may be a result of chronic liver infection such as hepatitis $B$ (HBV) or hepatitis C (HCV) viruses [24], the most common hepatic viral inflammatory diseases [26]. HBV is a double-stranded DNA virus [26] whose envelope is composed of 3 proteins: S (small), M (medium) and L (large). The overproduction of the protein envelope $\mathrm{L}$ leads to its intracellular accumulation in the hepatocytes and may lead to cancer induction, also viral polypeptides may be hepatotoxic and they might promote malignancy [27]. HBV can induce cancer development in an indirect manner by cellular oncogene activation and genetic disturbance by HBV-DNA integration. Conversely, HCV is a single-stranded RNA virus of cytoplasmic life cycle. $\mathrm{HCV}$ is able to produce liver environment by the initiation of cellular signalling and metabolic variations as well as immunomodulation by which it can escape from innate and adaptive immune responses. The production of this liver environment results in chronic inflammation, oxidative stress, and consequently liver fibrosis, cirrhosis and HCC overtime [26]. In addition, excessive alcohol consumption is one of the most dangerous causalities of liver cirrhosis. Alcohol is metabolized into acetaldehyde which is strongly toxic to hepatocytes and may lead to the formation of variable adducts capable of inactivating GSH and causing mitochondrial damages. Family history, obesity, aging and genetic diseases represented in diabetes, alpha-1 antitrypsin deficiency, hemochromatosis, tyrosinemia, porphyria, Wilson's disease, etc. are considered HCC risk factors [24]. In addition, the ingestion of aflatoxins (toxic molecules 
produced by parasitic fungi) such as aflatoxin B1, a genotoxic hepatocarcinogen, can cause HCC development by inducing the formation of DNA adducts, hence causing genetic changes in liver cells [28].

Artichoke extracts show highly impressive anticancer and protective activity against human HCC cell lines [29-31]. A study performed using methanolic extracts of fresh artichoke buds obtained from the external bracts and head using boiling methanol shows both cytotoxic and apoptotic effects against liver cancer cells. It shows a reduction in the viability of cancer cells up to $80 \%$ at the highest concentration, $1200 \mu \mathrm{mol} / \mathrm{L}$, when added to HepG2 cell lines. The extract also shows an apoptotic effect against HepG2 cell lines via the caspase-3 protein which is activated in response to treatment with 400 and $800 \mu \mathrm{mol} / \mathrm{L}$ of the artichoke extract and has led to apoptosis in about $50 \%$ of the cell population when cultivated for $24 \mathrm{~h}$ [32]. Extraction from different plant parts may lead to obtaining different active substances in the final extract; that is why the effect of these extracts may cause variable degrees of cell viability reduction when used for cancer treatment. For example, artichoke-heart methanolic extract shows reduction in the cell viability of human HepG2 cell lines by $36.7 \%$ while the bract extract shows $78.3 \%$ of cell reduction when each of them was applied for $2 \mathrm{~h}$ [33].

\section{Colorectal cancer}

Colorectal cancer (CRC) is one of the most globally spread cancers whose incidence ranks the second among women by 614,000 cases per year, and the third among men by 746,000 cases per year [34]. CRCs are classified according to their occurrence mechanisms into three major types: CIN, CIMP and MSI. CIN refers to chromosomal instability in which mutations in adenomatous polyposis coli (APC) occur leading to mutational activation of KRAs oncogene and consequently inactivation of the TP53 tumour suppressor gene [35]. Isolated methylator phenotype (CIMP or $\mathrm{CpG}$ ) results from the hypermethylation of some tumour suppressor genes, e.g. O-6-methylguanine-DNA methyltransferase (MGMT) and MutL homolog 1 (MLH1). The inactivation of these suppressor genes is associated with BRAFgene (a gene which encodes the B-Raf protein which is responsible for transferring signals inside the cells and during cellular growth) mutations and microsatellite instability (MSI). MSI tumour is a type that results from the inactivation of genetic alternation in short sequences of DNA called DNA-mismatch repair (MMR) [36]. Actually, Markowitz and Bertagnolli published a very informative review article summarizing the molecular basis of colorectal cancer [37].

A study of artichoke extracts, including a mixture of the heart and the vegetative part as well as the edible parts obtained from local and wild artichoke, in $n$-hexane, shows the excellent cytotoxicity of artichoke extracts against human DLD1 cancer cell line over the apigenin. The extracts not only suppress DLD1 cellular proliferation and growth but also induce apoptotic pathways via the up- and downregulation of the proapoptotic gene Bax and the anti-apoptotic gene $\mathrm{Bcl} 2$, respectively. DNA fragmentation results involved in this study show a 5-folds increase in Bax expression, while apigenin showed an elevation of 2.9-folds only. On the other hand, a decrease in Bcl2 expression level was observed revealing that the extracts induce programmed cell death by removing the anti-apoptotic $\mathrm{Bcl} 2$ barrier. Artichoke extracts were also found to upregulate the cyclin-dependant kinase inhibitor as well as p21, two of the most crucial apoptotic agents [38].

\section{Leukaemia and pleural mesothelioma}

Leukaemia is a word that refers to a cluster of diseases of variable biological background, prognosis and their action against treatment as well. Leukaemia can be a malignant transformation of the haematopoietic stem cells (HSCs) leading to the formation of abnormal mass of cells inhibiting the production of normal blood cellular components. Exposure to hazards, e.g. ionizing radiation, alkylating agents and benzene, is considered to be the most prominent factor that leads to leukaemia development [39]. The anti-proliferative activity of ethanolic artichoke bracts' extract was investigated by the treatment of both murine L1210 and HL-60 human cell lines with concentrations ranging from 500 to $2500 \mu \mathrm{g} / \mu \mathrm{L}$ for $24 \mathrm{~h}$. The study shows a decrease in cellular growth in a dose-dependent manner. It was proved that artichoke extract has a marked effect on the cancer cell cycle by arresting cells in the G0/G phase, while no cells were observed in the $\mathrm{S}$ phase. It also exhibit an apoptotic effect against the above-mentioned cell lines via mitochondrial caspase-dependant pathway, cytochrome-c release, caspase-9/caspase-3 activations, and specific proteolytic cleavage of poly(ADP-ribose) polymerase detected using western blot [40].

Mesothelioma is a neoplasm which mainly arises from the mesothelial cells lining the pleural, peritoneal and pericardial cavities. Exposure to fibrous minerals, e.g. asbestos, is one of the mesothelioma risk factors due to which over 20 million of people in the USA are in risk of mesothelioma development. The mesothelioma mortality rate is estimated to increase by $5-10 \%$ per year in most of the industrial countries by 2020 [41]. Ethanolic extracts of artichoke leaves also showed an inhibition in the growth and proliferation of MPM cell line associated with an apoptotic-inducing activity. The extract also inhibits the progression of tumour cells in vivo in MSTO-211H engrafted mice [42]. 


\section{Molecular mechanisms of polyphenols as antioxidants}

Polyphenols are present in many plants' leaves, fruits and flowers as pigments. A large number of polyphenols, exceeding 8000 structurally unparalleled compounds, have been separated from plant sources [43-46]. Polyphenols are the most plenteous and intensively studied antioxidant compounds. In addition, they have many other biological activities since they can act as antiinflammatory, anti-allergic, antithrombotic, antiviral and antitumor agents [16]. Therefore, it is necessary to clarify the molecular mechanism of their antioxidant action inside cancer and even normal cells. As mentioned above in this review, ROSs and RNSs create an intracellular state known as "oxidative stress" (Fig. 5) which result in serious cellular damage, carcinogenic reactions, neurodegenerative diseases, strokes, cardiovascular diseases, etc. [47, 48]. Researches on polyphenols confirmed that their antioxidant characters serve in preventing cancers, aging, diabetes and cardiovascular diseases $[49,50]$. It is well known in the literature that polyphenols exert their antioxidant action via four mechanisms: (i) ROSs and RNSs scavenging, (ii) enzyme regulation (through induction of antioxidant enzymes such as xanthine oxidase, lipoxygenase and NADPH oxidase), (iii) metal chelation (due to their high affinity to chelate iron and copper) and (iv) activation of calcium channels [51, 52]. In addition, polyphenols act as antioxidants by preventing the expression of some inflammatory signalling molecules, inhibiting platelet aggregation and vascular constriction [53, 54]. It is worth noting that naturally occurring polyphenols are often lipophilic at the physiological $\mathrm{pH}$; hence, they have ROSs and RNSs scavenging properties in hydrophobic media [16] (Fig. 5). Assaying the polyphenol scavenging capabilities can be performed through several assays procedures. These assays include Troxol-equivalent antioxidant capacity assay (TEAC), the 2,2-diphenyl-1-picrylhydrazyl (DPPH) radical scavenging assay, the ferric reducing ability assay (FRAP), the inhibition of $\mathrm{Cu}^{2+}$-induced plasma oxidation and the inhibition of red blood cell haemolysis induced by peroxyl radicals [55-57].

\section{Extraction methods of artichoke}

In this section, we will give a summary for the different solvent-extraction procedures followed in the literature in order to isolate artichoke medicinal compounds. Later on in this review, the effect of changing the extracting solvent on the yield of the extracted artichoke components will be highlighted.

\section{Alcoholic extraction}

Owing to the solubility properties of artichoke active components, alcohols are widely used in artichoke extraction [15, 29, 58-61]. Both methanol and ethanol

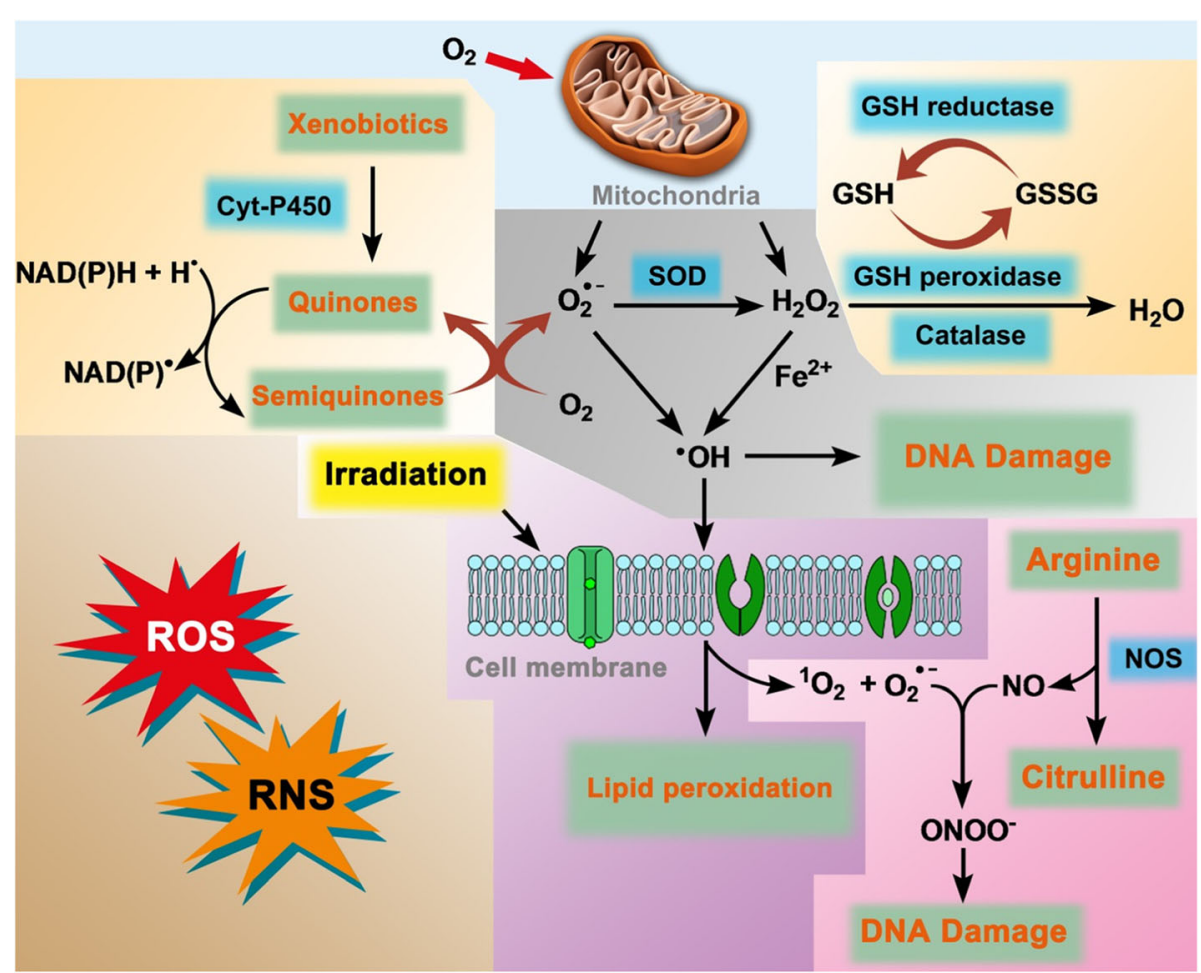

Fig. 5 Possible pathways leading to oxidative stress via production of ROSs and RNSs 
can be used in different concentrations either alone or in the form of mixtures. One method to extract free and bound phenolic compounds from artichoke heart and bracts was performed by dissolving $1 \mathrm{~g}$ of the flour of each part in $10 \mathrm{~mL}$ of $80 \%$ chilled ethanol for $20 \mathrm{~min}$ with continuous shaking [33]. The extract was then centrifuged at $2500 \mathrm{rpm}$ for $10 \mathrm{~min}$, the supernatant was collected, the residues were re-extracted twice with 10 $\mathrm{mL}$ of $80 \%$ chilled ethanol and the concentrated extract was dissolved in $10 \mathrm{~mL}$ methanol.

The residues obtained from the free phenolic compounds extraction step were hydrolysed in $20 \mathrm{~mL}$ of $\mathrm{NaOH}(2 \mathrm{M})$ with continuous shaking at $60{ }^{\circ} \mathrm{C}$ for 90 min. The hydrolysate was acidified to $\mathrm{pH} 2$ with $6 \mathrm{~N}$ $\mathrm{HCl}$ and centrifuged to get a cloudy precipitate. For the bound phenolic extract preparation, the clear supernatant was extracted 5 times in aqueous hexane of hexane/water $(1: 1, \mathrm{v} / \mathrm{v})$ to remove fatty acids and any other lipid contaminants. The obtained phenolic acid was extracted 6 times using ethanol/water mixture (1:1, $\mathrm{v} / \mathrm{v})$, evaporated to dryness and then dissolved in $10 \mathrm{~mL}$ methanol [33].

In another study, active compounds in artichoke leaves were extracted by dissolving $50 \mathrm{~g}$ of the dried leaves twice in $500 \mathrm{~mL}$ of $50 \%$ ethanol with $4 \mathrm{~h}$ continuous stirring at room temperature. Primary alcoholic extracts are then obtained and mixed in order to be dried under vacuum [22].

Reflux can also be used in order to perform an efficient extraction. For example, in a trial devoted to the extraction of artichoke leave components, $1 \mathrm{~kg}$ of powdered leaves was refluxed in $200 \mathrm{~mL}$ of $60 \%$ ethanol twice for 2 $\mathrm{h}$ then the extract was concentrated under reduced pressure at $50{ }^{\circ} \mathrm{C}$ and lyophilized. About $249 \mathrm{~g}$ of the crude extract was obtained, diluted with water and extracted with petroleum ether, ethanol and $n$-butanol to obtain four fractions after removing the solvents [62].

Artichoke buds are also rich in pharmaceutically active components which can be used in cancer therapy. In the work reported by Mileo et al. and Venere et al., 10 fresh artichoke buds of weights ranging from 115 to $125 \mathrm{~g}$ were obtained. The buds are composed of bracts and an edible part. About $25 \mathrm{~g}$ of the homogenized tissue were refluxed twice with boiling methanol $(1: 5, \mathrm{w} / \mathrm{v})$ for $1 \mathrm{~h}$. Thereafter, the extract was filtered and concentrated under vacuum. The obtained residues were dissolved in $100 \mathrm{~mL}$ of methanol/water $(1: 1, \mathrm{v} / \mathrm{v})$ mixture $[23,63]$.

About $880 \mathrm{~g}$ of artichoke bracts were extracted repeatedly with ethanol $(1: 10, \mathrm{w} / \mathrm{v})$ plant-to-solvent ratio for 2 weeks at room temperature. Thereafter, the solvent was evaporated by vacuum rotary evaporator at $40{ }^{\circ} \mathrm{C}$. Artichoke extract samples, that weigh about $100 \mathrm{mg}$, were extracted with $1.0 \mathrm{~mL}$ of $80 \%$ ethanol overnight with shaking at room temperature, sonicated in a water bath for $20 \mathrm{~min}$, vortexed for $10 \mathrm{~s}$ and finally centrifuged at $10^{4} \mathrm{rpm}$ for $10 \mathrm{~min}$. The resultant supernatant was collected and the procedures were repeated [40].

Sisto et al. used reflux to extract the pharmaceutically active components from artichoke buds. In this study, $100 \mathrm{~g}$ of fresh artichoke's edible part (buds) was homogenized by refluxing twice with boiling methanol (1:5, w/ v) for $1 \mathrm{~h}$. The extract was filtered, concentrated under reduced pressure with the aid of a rotary evaporator. A dry residue was obtained and dissolved in $500 \mathrm{~mL}$ of distilled water. The resulting solution was filtered, frozen and lyophilized to obtain the final dry powder [64].

For extraction of polyphenols, fresh samples of artichoke were dried at $50{ }^{\circ} \mathrm{C}$ for 2 days and stored at $4{ }^{\circ} \mathrm{C}$. A weight of $4 \mathrm{~g}$ of dried artichoke leaves or heads was homogenized and extracted by stirring with $100 \mathrm{~mL}$ aqueous methanol $(60 \%, \mathrm{v} / \mathrm{v})$ for $1 \mathrm{~h}$ at room temperature followed by filtration. The extracts were dried under vacuum at $30{ }^{\circ} \mathrm{C}$. The residues were dissolved in methanol to get a concentration of $10 \mathrm{mg} / \mathrm{mL}$ [65].

Dried Helianthus tuberosus leaves were ground into a fine powder. One gram of this powder was weighed and sonicated with $10 \mathrm{~mL}$ of ethyl acetate for $30 \mathrm{~min}$. The extracts were then filtered and the residues were reextracted twice with the same amount of the fresh solvent. The residues were dissolved in $10 \mathrm{~mL}$ of methanol and filtered [66].

\section{Aqueous extraction}

The literature contains many studies devoted to aqueous extraction of artichoke compounds from different parts of the plant [67-72]. Leaves $(120 \mathrm{~g})$ and flower $(160 \mathrm{~g})$ samples were collected and extracted by infusion with distilled water in 1:10 (w/v) plant-to-solvent ratio at 80 ${ }^{\circ} \mathrm{C}$ for $30 \mathrm{~min}$. The infusion was cooled down at room temperature, filtered, frozen and lyophilized [73].

Another aqueous extract of artichoke was prepared by dissolving $10 \mathrm{~g}$ of dried artichoke leaves in $200 \mathrm{~mL}$ of boiling distilled water for $5 \mathrm{~min}$, then the extract was allowed to cool down at room temperature [22].

Inulins are naturally occurring polysaccharides usually produced by many types of plants. They are characterized by their high water solubility; that is why they can be easily extracted via water extraction. In the literature, there are few methods devoted to inulin extraction from artichoke. Inulins were extracted from Jerusalem artichoke tubers which were collected, washed, cut and dried at $60{ }^{\circ} \mathrm{C}$ for $10 \mathrm{~h}$. The dried samples were finely powdered in order to be extracted using the accelerator solvent extractor (ASE). Thereafter, about $2 \mathrm{~g}$ of artichoke powdered tuber were added to $3.6 \mathrm{~g}$ of silica gel in an extractor cell, and then the powder was automatically extracted with water for $20 \mathrm{~min}$ at $80{ }^{\circ} \mathrm{C}$ and 1500 psi. The extraction process was controlled by the ASE time programme [74-77]. 
In another method for inulin extraction from Jerusalem artichoke, hearts were separated from bracts, sliced and dried in a $55{ }^{\circ} \mathrm{C}$ adjusted oven for 24 h to obtain constant weight. Sliced heart was powdered to particles of 0.63$1.25 \mathrm{~mm}$ size and then immersed in a specific quantity of distilled water and filtered. The resultant filtrate was collected for further two heating steps. Firstly, a conventional heating step was followed in which the filtrate is put into a container placed in a water bath with a stirring rate of 250 $\mathrm{rpm}$. The second step is an electromagnetic induction heating step in which the extraction process was carried out in a magnetisable enamelled container placed in an induction plate with a 250-rpm stirring rate. Magnesium salts as well as $\mathrm{Ca}(\mathrm{OH})_{2}$ were used in order to purify the extract at the end of the extraction procedures. The $\mathrm{pH}$ of the solution was adjusted to 9.4 with $\mathrm{NaOH}$. The clarification process was performed by continuous stirring at $70 \pm$ $2{ }^{\circ} \mathrm{C}$. After adjusting the solution $\mathrm{pH}$, specific volumes of $\mathrm{MgSO}_{4}$ followed by $\mathrm{Ca}(\mathrm{OH})_{2}$ were added to the solution to double the number of $\mathrm{OH}$ ions with respect to $\mathrm{Mg}$ ions. The obtained suspension was filtered, and the filtrate was subjected to a second clarification for $30 \mathrm{~min}$. Finally, ethanol precipitation was used to get the inulin from the obtained aqueous solution. The purified inulin was cooled at room temperature. A volume of ethanol was added with a $1: 3(\mathrm{v} / \mathrm{v})$ ratio, and the resultant suspension was centrifuged at $3461 \mathrm{rpm}$ for $5 \mathrm{~min}$ to get inulin pellet from the solution which was subsequently recovered and dried in air [78].

Ultra-pure water was used to extract the artichoke bracts via the microwave-assisted extraction (MAE) method. An amount of 0.1-0.3 g of dried artichoke bracts is placed in $100 \mathrm{~mL}$ green chem vessel which contains $10 \mathrm{~mL}$ of ultra-pure water and submitted to the MAE with microwave power of $900 \mathrm{~W}$ at a temperature range of $50-120{ }^{\circ} \mathrm{C}$ and a time range of $3-30 \mathrm{~min}$ [79].

Pressurized liquid extraction (PLE) is another method to obtain artichoke bract carbohydrates, e.g. inositols, sugars and inulin. In this method, a weight of $0.3 \mathrm{~g}$ of dried bracts was placed in $11 \mathrm{~mL}$ stainless steel extraction cell placed in between sand layers. Milli-Q water is used as extraction solvent and single static extraction cycle was set in all instances. The extraction process was carried out under pressure of 100 bar, and a nitrogen gas purge of 2 min was applied at the end of the extraction to ensure the complete discard of the solvent from cells. The extraction was performed under a temperature range of $40-120{ }^{\circ} \mathrm{C}$ and a time range of 3-30 $\mathrm{min}$ [79].

\section{Mixed solvents}

Artichoke bracts were subjected to two successive extraction processes. The first one was performed in order to extract phenolic acids, while the second was carried out in order to isolate flavonoids. Bracts were incubated at $4{ }^{\circ} \mathrm{C}$ for $1 \mathrm{~h}$ with acetone/ethanol/methanol (70:15:15, $\mathrm{v} / \mathrm{v} / \mathrm{v})$. The first supernatant was recovered and the residues were then treated with ethanol in a ratio of $1: 3(\mathrm{w} /$ v) and stored at $4{ }^{\circ} \mathrm{C}$ for $1 \mathrm{~h}$. The two supernatants were dried separately using an air flow and then re-dissolved in ethanol, pooled and stored at $-30{ }^{\circ} \mathrm{C}$ in the dark for subsequent use [80].

\section{Other solvents}

Using $n$-hexane, head, vegetative and edible parts of the two artichoke species (C. cardunculus and $C$. syriaca) were dried at $110{ }^{\circ} \mathrm{C}$ for $5 \mathrm{~h}$. Thereafter, $25 \mathrm{~g}$ of the dried powder of each part was subjected to liquid extraction for $6 \mathrm{~h}$ in Soxhlet's apparatus with $n$-hexane, then the solvent was evaporated using a rotary evaporator at $40{ }^{\circ} \mathrm{C}$ to obtain the three extracts [38].

Artichoke air-dried leaves were soaked in dichloromethane $(10 \mathrm{~mL} / \mathrm{g}$ dry weight) for $5 \mathrm{~min}$, filtered, dried under vacuum and re-dissolved in methanol. The solution was filtered to discard methanol-insoluble substances. Methanol extract was diluted with the same volume of water [81].

For callus production, Jerusalem artichoke tubers were collected, washed with tap water and soap, and stored in the darkness. The sprouting tubers were sterilized by immersion in $70 \%$ ethanol for $10 \mathrm{~s}$, washed 3 times with distilled water and then immersed in 50\% commercial Clorox solution with 2 drops of Tween-20 for $15 \mathrm{~min}$. Sprouts were rinsed repeatedly with sterilized distilled water and cultured on basal solid MS-medium. Prior to autoclaving at $1.2 \mathrm{~kg} / \mathrm{cm}^{2}$ for $15 \mathrm{~min}, 0.7 \%$ agar was used to solidify the cultures. The medium $\mathrm{pH}$ was adjusted to 5.8 with $0.1 \mathrm{~N} \mathrm{HCl}$ and $0.1 \mathrm{~N} \mathrm{NaOH}$. Cultivation was carried out with $50 \mathrm{~mL}$ of basal solid MS-medium in a 300-mL glass jar. Leaves' segments were removed after a few days from the shootlets and used as a stock for callus production [82].

\section{Aspects influenced by extraction methods Extraction yield}

Many compounds can be obtained from the extraction of different parts of artichoke based on the extraction conditions including type and concentration of the extracting solvents (Fig. 6), variations in the extraction procedures, degree of acidification, temperature and extraction duration. These compounds including polyphenols, flavonoids, carbohydrates, sesquiterpene lactones ...etc. are shown to have potent anticancer activities when applied to different cancer types. In the following part, we will address the effect of the factors on the yields of the most commonly studied artichoke compounds in the literature which consequently affect the anticancer activity of the obtained extract. 


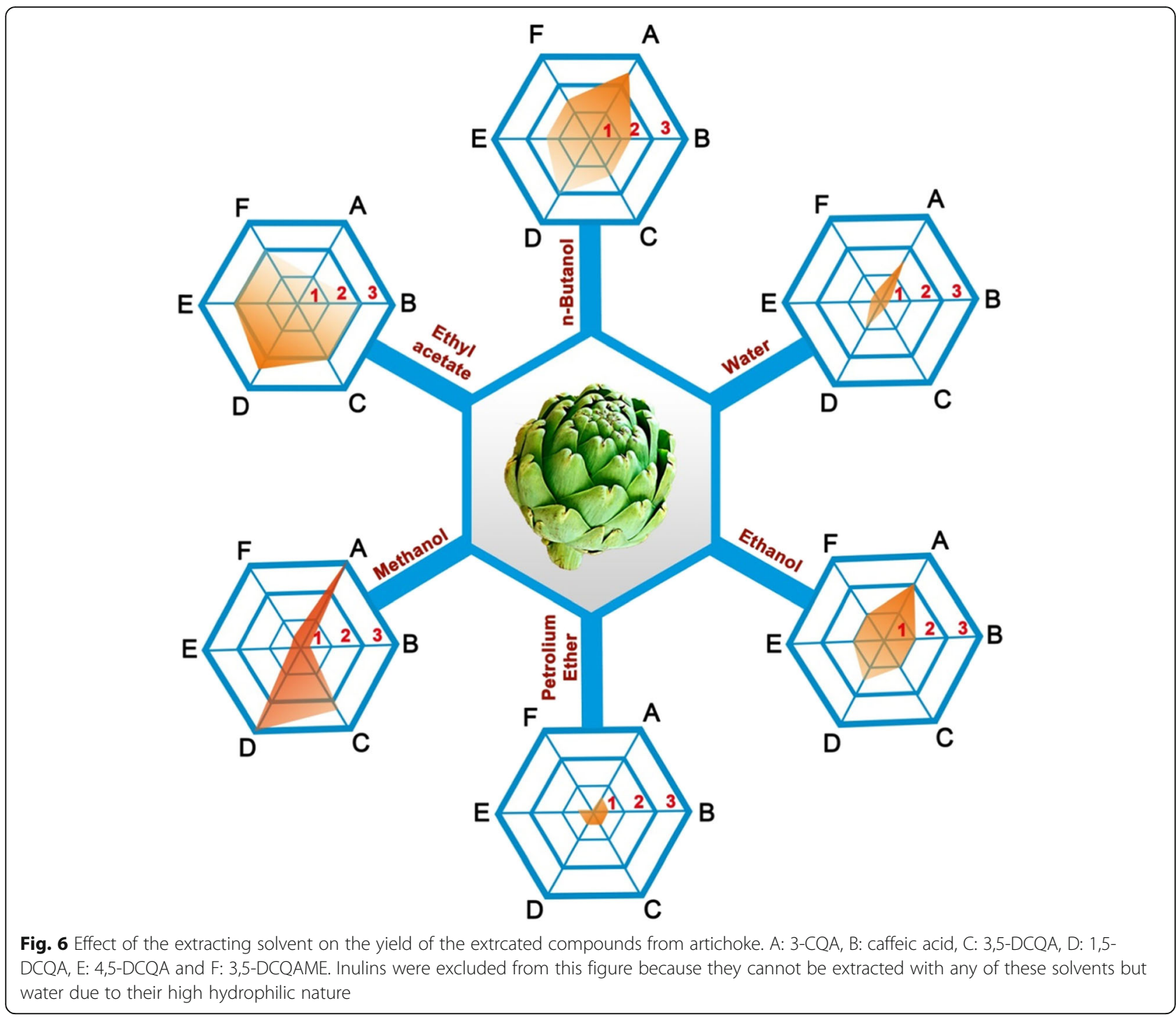

\section{Polyphenols}

As described above, polyphenols are well-known compounds of their unique chemical composition and health benefits to humans [83-85]. They are common free radical scavengers and potent chemopreventing agents against pro-neoplastic and neoplastic cancers. This family of plant compounds can induce apoptotic effects against cancer cells via the growth inhibitory mechanisms including the activation of cytochrome $\mathrm{c}$ and caspases, arresting the cell cycle and modulating cell-signalling pathways NF- $\mathrm{B}$, JAK/STAT resulting in tumour suppression [86].

Flavonoids, gallic acid, chlorogenic acid, caffeic acid and all caffeoylquinic acid (CQA) derivatives are polyphenol compounds that belong to the most powerful artichoke compounds proved to have promising anticancer activities [87-95]. Variations in the extraction procedures of these phenolic compounds from artichoke different parts can affect their yield. Eighty percent chilled ethanol was used to extract artichoke heart and bracts to obtain both bound and free phenolic compound as described previously in this review. This method results in $9.06 \pm 0.06$ and $5.38 \pm 0.08$ as well as $14.16 \pm 0.08$ and $4.20 \pm 0.07 \mathrm{mg} / \mathrm{g}$ of free and bound phenolic compounds, respectively [33].

Using $60 \%$ ethanol to dissolve artichoke leaves at 50 ${ }^{\circ} \mathrm{C}$ is a promising method to obtain $101.07 \pm 0.63 \mathrm{mg} / \mathrm{g}$ dried sample of total polyphenols divided into 3-CQA (30.42 \pm 0.37$)$, caffeic acid (2.12 \pm 0.09$), 3,5-\mathrm{DCQA}(1.47$ $\pm 0.15), 1,5$-DCQA $(8.27 \pm 0.54), 4,5$-DCQA $(2.17 \pm$ $0.21)$, and 3,5-DCQAME $(0.53 \pm 0.05)$. When the dried crude extract was further extracted with petroleum ether, ethyl acetate (EA) and $n$-butanol, it resulted in three more fractions. The results show that EA had the highest content of total polyphenols $(266.69 \pm 2.51 \mathrm{mg} / \mathrm{g}$ dried sample) including caffeic acid (13.83 \pm 0.44$)$, 3,5- 
DCQA $(27.18 \pm 1.59), 1,5$-DCQA (104.51 \pm 2.86$), 4,5$ DCQA (19.29 \pm 0.44$)$ and 3,5-DCQAME $(20.67 \pm 0.83)$. In spite of the highest phenolic content of the ethyl acetate fraction, it shows a few content of 3-CQA (19.84 \pm 0.61 ) compared to the $n$-butanol fraction that shows the highest 3-CQA content of $74.58 \pm 1.05$. $n$-butanol fraction was ranked the second according to the amount of phenolic compounds $(135.72 \pm 1.07)$ subdivided as following: 3-CQA (74.58 \pm 1.05$)$, caffeic acid (3.36 \pm 0.33$)$, 3,5DCQA ( $2.21 \pm 0.19), 1,5$-DCQA (15.87 \pm 1.09$), 4,5$-DCQA $(3.41 \pm 0.21)$ and 3,5-DCQAME $(0.81 \pm 0.12)$. The petroleum ether fraction shows moderate content of yields by (31.89 \pm 0.42$)$ for total phenolics, 3-CQA $(2.11 \pm 0.09)$, caffeic acid (1.56 \pm 0.03$), 3,5$-DCQA $(0.42 \pm 0.03), 1,5-$ DCQA $(1.59 \pm 0.09)$ and 4,5-DCQA $(0.41 \pm 0.09)$, while the 3,5-DCQAME content was not detected [62].

The heads and leaves of green globe and violet artichokes were extracted using $60 \%$ aqueous methanol. The results of the HPLC analysis of the obtained extracts show that the green globe extract have a total phenolic content of $8.603 \pm 0.265$ and $2.697 \pm 0.116 \mathrm{~g}$ chlorogenic acid/100 g dry weight. On the other hand, the violet leaves and head extracts show $5.666 \pm 0.257$ and $1.818 \pm 0.243 \mathrm{~g}$ chlorogenic acid/100 g dry weight, respectively. The content of 1,3-DCQA in the green globe leaves and head extracts was 1.5823 and $0.2792 \mathrm{~g} /$ $100 \mathrm{~g}$ dry weight, while in violet leaves and head extracts, it was found to be 1.4952 and $0.1936 \mathrm{~g} / 100 \mathrm{~g}$ dry weight, respectively [65].

In another study, refluxing $25 \mathrm{~g}$ of artichoke edible part with boiling methanol results in the accumulation of $730 \pm 78 \mathrm{mg} / \mathrm{L}$ of chlorogenic acid as well as $745 \pm 62$ and $645 \pm 54 \mathrm{mg} / \mathrm{L}$ of 3,5-DCQA and 1,5-DCQA, respectively [23].

Using acetone/ethanol/methanol mixture (70:15:15, v/ $\mathrm{v} / \mathrm{v}$ ) for the extraction of artichoke bracts was used to produce a total polyphenols yield of $525.49 \pm 0.11 \mu \mathrm{g}$ gallic acid equivalent/g dry weight. These extracts contained 2.80, 136.75 and $171.58 \mu \mathrm{g}$ gallic acid equivalent/ g dry weight for gallic acid, chlorogenic acid and 1,3DCQA, respectively [80].

Artichoke leaf extraction with 50\% ethanol gave a yield of $34.3 \%$ of total polyphenols subdivided as $10.33 \%$ CQA, 8.27\% flavonoids and 4.07\% chlorogenic acid [42].

\section{Sesquiterpene lactones}

Alcoholic extraction is one of the preferred extraction methods for the separation of sesquiterpene lactones (SLs). Using methanol to extract the dichloromethanesoaked artichoke leaves is a method by which about 22 different SLs were obtained. Also, extraction of artichoke leaves collected from different areas with ethanol for 30 min led to separation of 11 SLs with a yield reaching $1664.76 \mu \mathrm{g} / \mathrm{g}$ [81].
Table 1 summarises the methods of extraction of artichoke components and the corresponding yields obtained from each method.

\section{Cancer cellular growth and proliferation}

Literature survey reveals that previous studies on artichoke-extract-based anticancer treatment show variation in cancer cellular growth and proliferation. From this point, we summarize here the results obtained upon using different extraction methods of artichoke (see Table 2).

Artichoke leaves' components extracted from 5 to $6: 1$ DER with $50 \%$ ethanol were found to be rich in caffeoyl quinic acids, chlorogenic acid and cynaropicrin, all of which have potent anticancer activity. The extract was applied on MSTO-211H, MPP-89 and NCI-H28, mesothelioma cell lines and normal untransformed mesothelial cells $(\mathrm{HMC})$ with an increasing concentration range of $3-200 \mu \mathrm{g} / \mathrm{mL}$ for $72 \mathrm{~h}$. The results shows an apparent dose-dependent reduction in cell viability of MSTO211H, MPP-89 and NCI-H28 mesothelioma cell lines with $\mathrm{IC}_{50}$ values of $21.08,17.80$ and $28.08 \mu \mathrm{g} / \mathrm{mL}$, respectively, while normal cells were found to be resistant to the growth inhibitory effect of the extract. The extract also showed anti-invasion effect on mesothelioma cell lines as it inhibited their migration in a time-dependent manner when 6 and $12 \mu \mathrm{g} / \mathrm{mL}$ of artichoke-leaf extract was applied to both MSTO-211H and MPP- 89 for different time intervals $(0,12,24$ and $36 \mathrm{~h})$, the process that resulted in migration inhibition of both cell types by 50 and 35\%, respectively [42].

Extracting artichoke buds with boiling methanol has led to accumulation of caffeoylquinic as well as chlorogenic acids, both of which have a potent cytotoxic effect on HepG2 cell lines when used with a concentration range of $400-1200 \mu \mathrm{M}$ for 24,48 and $72 \mathrm{~h}$. Cell viability was reduced in a time- and dose-dependent manner. Applying the extract with the highest concentration of $1200 \mu \mathrm{M}$ for $24 \mathrm{~h}$ has led to $80 \%$ cell death, while $50 \%$ cell death was obtained when $800 \mu \mathrm{M}$ was applied for 48 and $72 \mathrm{~h}$. The cell death percentage remains constant when the highest concentration $1200 \mu \mathrm{M}$ is applied for $72 \mathrm{~h}$ [32]. Both aqueous and ethanolic leaf extracts show cytotoxic activity when applied against T-47D and ZR75-1 breast cancer cell lines [22].

Polyphenol content obtained from the boiled methanolic extract of artichoke edible part show marked cytotoxic activity against MDA-MB 231 cell lines when incubated with a concentration range of $200-800 \mu \mathrm{M}$ for $24 \mathrm{~h}$ [23]. A dose of $600 \mu \mathrm{M}$ shows about $60 \%$ cellular death, while the highest concentration shows about $80 \%$. The extract was also applied on BT549, T47D and MCF-7 cells as well as the MCF-10A normal cells and resulted in a significant reduction of cancer cell viability, 
Table 1 Methods used for extraction of artichoke components, their yield and application in cancer treatments

\begin{tabular}{|c|c|c|c|c|}
\hline Extraction method & Yield & Cancer type & Viability \% & Reference \\
\hline \multirow[t]{2}{*}{ Aqueous } & Not included & $\begin{array}{l}\text { Breast cancer } \\
\text { (T-47D) }\end{array}$ & $4-5$ times decrease & [22] \\
\hline & & $\begin{array}{l}\text { Breast cancer } \\
\text { (ZR-75-1) }\end{array}$ & $6-8.5$ times decreased & \\
\hline \multirow[t]{9}{*}{$50 \%$ ethanol } & Scopoletin & $\begin{array}{l}\text { Breast cancer } \\
\text { (T-47D) }\end{array}$ & 8-9 times decrease & {$[22]$} \\
\hline & Apigenin & ZR-75-1 & 10-13 times decrease & \\
\hline & Diosmetin & & & \\
\hline & Isohoifolin & & & \\
\hline & Salvigenin & & & \\
\hline & Naringin dihydrochalcone & & & \\
\hline & Ursolic acid & & & \\
\hline & Stearidonic acid methyl ester & & & \\
\hline & Stearidonic ethyl ester & & & \\
\hline \multirow[t]{9}{*}{ Methanol } & Chlorogenic acid: $725 \pm 70 \mathrm{mg} / \mathrm{L}$ & Prostate (DU 145) & $50 \%$ & {$[23,96]$} \\
\hline & 3,5-Dicaffeoylquinic acid (DCQA): $738 \pm 58 \mathrm{mg} / \mathrm{L}$ & Melanoma (M14) & $50 \%$ & \\
\hline & 1,5-DCQA: $632 \pm 48 \mathrm{mg} / \mathrm{L}$ & $\begin{array}{l}\text { Breast (MDA- } \\
\text { MB231) }\end{array}$ & $17 \%$ & \\
\hline & & Ovary (HEY) & $30 \%$ & \\
\hline & & Lung (A549) & $32 \%$ & \\
\hline & & Brain (U-373 MG) & $17 \%$ & \\
\hline & & Bone (Saos-2) & $20 \%$ & \\
\hline & & $\begin{array}{l}\text { Leukaemia } \\
\text { (K-562) }\end{array}$ & $17 \%$ & \\
\hline & & $\begin{array}{l}\text { Breast (BT549, } \\
\text { T47D and MCF-7) }\end{array}$ & $20 \%$ & \\
\hline \multirow[t]{4}{*}{ Ethanol } & Heart total phenolic compounds (TPC): $9.06 \pm 0.06 \mathrm{mg} / \mathrm{g}$ & Liver (HePG2) & $\begin{array}{l}\text { Heart-free phenolic extract } \\
\text { shows } 36.7 \% \text { at } 100 \text { ppm }\end{array}$ & {$[33]$} \\
\hline & Heart total flavonoid compounds (TFC): $5.91 \pm 0.12 \mathrm{mg} / \mathrm{g}$ & & $\begin{array}{l}\text { Heart-bound phenolic } \\
\text { extract shows } 27.2 \% \text { at } 100 \\
\text { ppm }\end{array}$ & \\
\hline & Bracts (TPC): $14.16 \pm 0.08 \mathrm{mg} / \mathrm{g}$ & & $\begin{array}{l}\text { Bract-free phenolic extract } \\
\text { shows } 75.3 \% \text { at } 100 \text { ppm }\end{array}$ & \\
\hline & Bracts (TFC): $9.85 \pm 0.12 \mathrm{mg} / \mathrm{g}$ & & $\begin{array}{l}\text { Bract bound phenolic } \\
\text { extract shows } 14 \% \text { at } 100 \\
\text { ppm }\end{array}$ & \\
\hline \multirow[t]{12}{*}{ Methanol } & Mono-caffeoylquinic acid 1: $17 \pm 2 \mathrm{mg} / \mathrm{L}$ & Liver (HePG2) & $20 \%$ & {$[32]$} \\
\hline & Mono-caffeoylquinic acid 2: $13 \pm 1 \mathrm{mg} / \mathrm{L}$ & & & \\
\hline & Chlorogenic acid: $730 \pm 78$ mg/L & & & \\
\hline & Mono-caffeoylquinic acid 3: $17 \pm 2 \mathrm{mg} / \mathrm{L}$ & & & \\
\hline & Di-caffeoylquinic acid 1: $4 \pm 0.5 \mathrm{mg} / \mathrm{L}$ & & & \\
\hline & Di-caffeoylquinic acid 2: $8 \pm 1 \mathrm{mg} / \mathrm{L}$ & & & \\
\hline & Di-caffeoylquinic acid 3: $16 \pm 2 \mathrm{mg} / \mathrm{L}$ & & & \\
\hline & Di-caffeoylquinic acid 4: $745 \pm 62 \mathrm{mg} / \mathrm{L}$ & & & \\
\hline & Di-caffeoylquinic acid 5: $645 \pm 54 \mathrm{mg} / \mathrm{L}$ & & & \\
\hline & Di-caffeoylquinic acid 6: $35 \pm 3 \mathrm{mg} / \mathrm{L}$ & & & \\
\hline & Luteolin-glycoside: $23 \pm 5 \mathrm{mg} / \mathrm{L}$ & & & \\
\hline & Apigenin-glycoside: $25 \pm 5$ mg/L & & & \\
\hline
\end{tabular}


Table 1 Methods used for extraction of artichoke components, their yield and application in cancer treatments (Continued)

\begin{tabular}{|c|c|c|c|c|}
\hline Extraction method & Yield & Cancer type & Viability $\%$ & Reference \\
\hline Ethanol & $\begin{array}{l}3.44 \% \text { of total hydroxycinnamic acids expressed as } \\
\text { chlorogenic acid and } 0.4 \% \text { of total flavonoid content } \\
\text { calculated as luteolin }\end{array}$ & $\begin{array}{l}\text { Leukaemia (L1210 } \\
\text { and HL-60 cells) }\end{array}$ & $<20 \%$ of cellular growth & {$[40]$} \\
\hline \multirow[t]{2}{*}{ Ethanol } & $\begin{array}{l}\text { Caffeoylquinic acid derivatives: } 10.33 \% \text { of } 34.251 \% \text { of } \\
\text { polyphenols }\end{array}$ & \multirow{2}{*}{$\begin{array}{l}\text { Pleural } \\
\text { mesothelioma } \\
\text { (MSTO-211H) }\end{array}$} & \multirow[t]{2}{*}{ Not included } & \multirow[t]{2}{*}[42]{} \\
\hline & Saccharides (\%): 24.69 & & & \\
\hline \multirow[t]{7}{*}{ Ethanol } & Total phenolics: $101.07 \pm 0.63 \mathrm{mg} / \mathrm{g}$ & \multirow[t]{7}{*}{ Not included } & \multirow[t]{7}{*}{ Not included } & \multirow[t]{7}{*}[62]{} \\
\hline & 3-CQA: $30.42 \pm 0.37 \mathrm{mg} / \mathrm{g}$ & & & \\
\hline & Caffeic acid $2.12 \pm 0.09 \mathrm{mg} / \mathrm{g}$ & & & \\
\hline & 3,5-DCQA: $1.47 \pm 0.15 \mathrm{mg} / \mathrm{g}$ & & & \\
\hline & 1,5-DCQA: $8.27 \pm 0.54 \mathrm{mg} / \mathrm{g}$ & & & \\
\hline & 4,5-DCQA: $2.17 \pm 0.21 \mathrm{mg} / \mathrm{g}$ & & & \\
\hline & 3,5-DCQAME: $0.53 \pm 0.05$ mg/g & & & \\
\hline \multirow{7}{*}{$\begin{array}{l}\text { Re-extracting crude } \\
\text { extract with petroleum } \\
\text { ether }\end{array}$} & Total phenolics: $31.89 \pm 0.42 \mathrm{mg} / \mathrm{g}$ & \multirow[t]{7}{*}{ Not included } & \multirow[t]{7}{*}{ Not included } & \multirow[t]{7}{*}[62]{} \\
\hline & 3-CQA: $2.11 \pm 0.09 \mathrm{mg} / \mathrm{g}$ & & & \\
\hline & Caffeic acid: $1.56 \pm 0.03 \mathrm{mg} / \mathrm{g}$ & & & \\
\hline & 3,5-DCQA: $0.42 \pm 0.03 \mathrm{mg} / \mathrm{g}$ & & & \\
\hline & 1,5-DCQA: $1.59 \pm 0.09 \mathrm{mg} / \mathrm{g}$ & & & \\
\hline & 4,5-DCQA: $0.41 \pm 0.09 \mathrm{mg} / \mathrm{g}$ & & & \\
\hline & 3,5-DCQAME: ND & & & \\
\hline \multirow{7}{*}{$\begin{array}{l}\text { Re-extracting crude } \\
\text { extract with ethyl } \\
\text { acetate }\end{array}$} & Total phenolics: $266.69 \pm 2.51 \mathrm{mg} / \mathrm{g}$ & \multirow[t]{7}{*}{ Not included } & \multirow[t]{7}{*}{ Not included } & \multirow[t]{7}{*}[62]{} \\
\hline & 3-CQA: $9.84 \pm 0.61 \mathrm{mg} / \mathrm{g}$ & & & \\
\hline & Caffeic acid: $13.83 \pm 0.44$ mg/g & & & \\
\hline & 3,5-DCQA: $27.18 \pm 1.59 \mathrm{mg} / \mathrm{g}$ & & & \\
\hline & 1,5-DCQA: $104.51 \pm 2.86$ mg/g & & & \\
\hline & 4,5-DCQA: $19.29 \pm 0.44 \mathrm{mg} / \mathrm{g}$ & & & \\
\hline & 3,5-DCQAME: $20.67 \pm 0.83 \mathrm{mg} / \mathrm{g}$ & & & \\
\hline \multirow{7}{*}{$\begin{array}{l}\text { Re-extracting crude } \\
\text { extract with n-butanol }\end{array}$} & Total phenolics: $135.72 \pm 1.07$ mg/g & \multirow[t]{7}{*}{ Not included } & \multirow[t]{7}{*}{ Not included } & \multirow[t]{7}{*}{ [62] } \\
\hline & 3-CQA: $74.58 \pm 1.05 \mathrm{mg} / \mathrm{g}$ & & & \\
\hline & Caffeic acid: $3.36 \pm 0.33 \mathrm{mg} / \mathrm{g}$ & & & \\
\hline & 3,5-DCQA: $2.21 \pm 0.19$ mg/g & & & \\
\hline & 1,5-DCQA: $15.87 \pm 1.09 \mathrm{mg} / \mathrm{g}$ & & & \\
\hline & 4,5-DCQA: $3.41 \pm 0.21 \mathrm{mg} / \mathrm{g}$ & & & \\
\hline & 3,5-DCQAME: $0.81 \pm 0.12 \mathrm{mg} / \mathrm{g}$ & & & \\
\hline \multirow{4}{*}{$\begin{array}{l}\text { Re-extracting crude } \\
\text { extract with water }\end{array}$} & Total phenolics: $52.45 \pm 1.44$ mg/g & \multirow[t]{4}{*}{ Not included } & \multirow[t]{4}{*}{ Not included } & \multirow[t]{4}{*}[62]{} \\
\hline & 3-CQA: $20.64 \pm 0.76 \mathrm{mg} / \mathrm{g}$ & & & \\
\hline & 1,5-DCQA: $7.94 \pm 0.39 \mathrm{mg} / \mathrm{g}$ & & & \\
\hline & Caffeic acid; 3,5-DCQA; 4,5-DCQA and DCQAME: ND & & & \\
\hline
\end{tabular}

while no effect was noticed against the normal cells. The MDA-MB 231 cells were incubated with the extract $(100-400 \mu \mathrm{M})$ for 6 days in order to detect the proliferation inhibitory effect of the extract. The observed inhibitory effect was obtained at a concentration of $200 \mu \mathrm{M}$ after 3-6 days of exposure, and the optimum inhibitory effect was at a concentration of $400 \mu \mathrm{M}$ at which the cellular proliferation was completely inhibited [23]. The application of boiled methanolic artichoke extract on MDA-MB 231 breast cancer cell lines for 10 days with extract concentration range of $2.5-60 \mu \mathrm{M}$ results in cellular growth inhibition by $90 \%$ when low doses up to 30 
Table 2 Effect of solvent extraction methods on the biological activity of artichoke extract

\begin{tabular}{ll}
\hline Solvent & Anticancer activity \\
\hline Ethanol & *Leukaemia (L-120 and HL-60): 60-90\% anti-proliferation \\
& ${ }^{*}$ Liver (HepG2): 50-80\% (cellular death) \\
& ${ }^{*}$ Mesothelioma (MSTO-211H and MPP-89): migration inhibition by 50 and 35\%, respectively \\
Methanol & ${ }^{*}$ Liver (HepG2): 50-80\% (cellular death) \\
& ${ }^{*}$ Breast (MCF-7, T47D and BT549): 60-80\% (cellular death) \\
& *Prostate and melanoma: about 50\% (cellular death) \\
& ${ }^{*}$ Ovary, lung, brain, bone and leukaemia: $>50 \%$ (cellular death) \\
Hexane & ${ }^{*}$ Colon (DLD1): 20-100\% (cellular death) \\
\hline
\end{tabular}

$\mu \mathrm{M}$ was used, while the highest concentration of $60 \mu \mathrm{M}$ achieved inhibition for about $70 \%$ of the cells [96].

Interestingly, incubating different human cancer cell lines with $800 \mu \mathrm{M}$ of boiled methanolic extract of the artichoke edible part for $24 \mathrm{~h}$ shows impressive results in cellular death which reaches $50 \%$ in the case of prostate and melanoma cells and more than $50 \%$ in the case of breast, ovary, lung, brain, bone, and leukaemia cancer cells. Some drug-resistant cells, e.g. colon and gastric cancer cells, were found to have $<50 \%$ of dead cells when incubated with $800 \mu \mathrm{M}$ while they showed higher sensitivity to the 1200- $\mu \mathrm{M}$ dose [96].

Different fractions are obtained from wild and globe artichoke vegetative and head parts when extracted with hexane for $6 \mathrm{~h}$. The three fractions were applied on the colorectal cancer cell line DLD1 using a concentration range of $100-1000 \mu \mathrm{g} / \mathrm{mL}$ for 24,48 and $72 \mathrm{~h}$, and the results show significant reduction in cell viability in a dose-dependent manner except for one of the fractions which shows cell viability inhibition in dose- and timedependent manner [38].

Anti-proliferative effect of artichoke-bracts ethanolic extract against L1210 and HL-60 leukaemia cell lines was shown when applied for $24 \mathrm{~h}$ with a concentration range of $500-2500 \mu \mathrm{g} / \mu \mathrm{L}$. The obtained data shows that the anti-proliferative effect for L1210 and HL-60 cell lines was 80 and 90\%, respectively, by applying the highest concentration $(2500 \mu \mathrm{g} / \mu \mathrm{L})$. However, a dose of 1250 $\mu \mathrm{g} / \mu \mathrm{L}$ shows $60 \%$ cellular anti-proliferation for both cell types. By using a dose of $500 \mu \mathrm{g} / \mu \mathrm{L}$, only $20 \%$ of antiproliferative effect was shown for L1210 cells and no change occurred in case of HL-60 [40].

Artichoke extract shows reduction in HepG2 cancer cell viability up to $80 \%$ at the highest concentration applied, $1200 \mu \mathrm{M}$. Artichoke extract also shows apoptotic effect against HepG2 cell lines via the caspase- 3 protein which is activated in response to treatment with 400 and $800 \mu \mathrm{M}$ concentration for $24 \mathrm{~h}$ leading to apoptosis in about $50 \%$ of cell population [32]. Artichoke heart methanolic extract showed reduction in cell viability of human HepG2 cell lines by $36.7 \%$, while bract extract showed a cell reduction of $75.3 \%$ when both were applied for $24 \mathrm{~h}$ [33].

\section{Apoptotic activity}

Apoptosis or the programmed cell death is one of the most common cancer-killing pathways. It is the method of cell death that occurs under certain physiological conditions due to some intracellular changes. Many factors affect apoptosis induction by drugs including stress inducers, e.g. NF-KB, INK, MAPK, ERK, granzyme B released by cytotoxic $\mathrm{T}$ cells and activates the downstream apoptosis effector mechanism and proteolytic enzymes, i.e. caspases. These factors are considered the "apoptosis soldiers" through which the apoptosis process can be stimulated in the target cell and represented in cell shrinkage, nuclear DNA fragmentation and membrane protrusion [97-103].

Caspases are proteolytic enzymes that belong to the "cysteine protease" family and act as death-effector molecules. These proteins are divided into two categories: initiator and effector caspases. Initiator caspases (e.g. caspase- 8 and caspase-10) are responsible for signal transduction into protease activity, and they are directly linked to death-inducing-signals complexes (DISCs), while effector caspases possess varieties of cytoplasmic and nuclear substrates which are responsible for many morphologic features of apoptotic cell death [104-108]. Initiator caspases can be activated by two pathways, hence inducing apoptosis. These pathways are (i) the receptor pathway by which caspase is activated by deathreceptor-mediated signalling pathway at the plasma membrane and (ii) the mitochondrial pathway that takes place in the mitochondria. The receptor pathway begins with stimulation of TNF superfamily, e.g. CD95 (Apo-1/ Fas) or TRAIL receptor, resulting in receptor aggregation followed by recruitment of adaptor molecules such as Fas-associated death domain (FADD) and caspase- 8 which induces apoptosis by cleavage of downstream effector caspases when activated [109-111]. The mitochondrial pathway is initiated with the release of apoptogenic factors from the mitochondrial intramembrane space, e.g. cytochrome c, apoptotic-inducing factor (AIF) and caspase- 2 or 9 [112-117]. Releasing cytochrome $c$ in cytosol triggers caspase-3 activation via forming cytochrome/Apof-1/caspase-9 containing apoptosome complex [118]. Both pathways can be connected as after 
death receptor stimulation, the resultant caspase- 8 activation leads to Bid cleavage (a $\mathrm{BH} 3$ domain containing $\mathrm{Bcl} 2$ family protein) which assumes cytochrome c releasing activity upon cleavage and then induces the mitochondrial pathway $[119,120]$.

Repeated extraction of artichoke bracts with ethanol for 2 weeks showed remarkable apoptotic effect against leukaemia cell lines, represented in cytochrome c release in leukaemia cells treated with $1250 \mu \mathrm{g} / \mu \mathrm{L}$ of the extract for $8 \mathrm{~h}$. Release of cytochrome c plays a crucial rule in the mitochondrial pathway which leads to caspase-3 activation which in turn initiates the apoptotic pathway [40]

In another study, ethanolic extraction of artichoke leaves was proved to have apoptotic effect against MSTO-211H and MPP-89 cell lines treated for $24 \mathrm{~h}$ with $100 \mu \mathrm{g} / \mathrm{mL}$ via triggering the cleavage of caspase-3 and caspase-7 as well as poly-ADP ribose protein1(PARP-1) [42] which is considered one of the caspase substrates being cleaved by the caspase proteolytic activity. PARP-1 cleavage leads to the formation of variant fragments that mediate cell death, and its presence is known to be an apoptotic hallmark [121-123].

Artichoke bud extraction with boiled methanol shows a significant apoptotic activity against HepG2 hepatocellular carcinoma cell lines. This promising activity is represented by more than $50 \%$ apoptotic cell population achieved by application of $800 \mu \mathrm{M}$ of artichoke extract to the cells, while there was an early apoptosis in control by $15 \%$. The highest concentration of $1200 \mu \mathrm{M}$ caused $65 \%$ apoptosis to the cells. Additionally, applying $1.5 \mu \mathrm{M}$ of artichoke extract caused $50 \%$ of apoptotic cell death after $24 \mathrm{~h}$. Activation of cellular caspase-3 in human hepatoma cells HepG2 is achieved when incubated with 400 and $800 \mu \mathrm{M}$ of the artichoke extract, while the highest concentration of $1200 \mu \mathrm{M}$ shows less caspase-3 activation than that of the low concentrations. This finding may be due to the presence of necrotic or apoptotic cells. ChA, one of the phenolic components of the extract, was applied to the hepatoma cells for $48 \mathrm{~h}$, and it showed a significant increase in the apoptotic cell death that reaches $50 \%$ with the highest concentration $(1200 \mu \mathrm{M})$ [32].

Boiled methanol extraction of artichoke buds was found to have an impressive effect on the apoptotic pathway induced by caspase- 8 and caspase- 9 against MDA-MB231 when incubated with the extract (200-800 $\mu \mathrm{M})$ for $24 \mathrm{~h}$. Caspase- 8 activation was detected at the lowest dose $(200 \mu \mathrm{M})$, while caspse-9 activation increased in a dose-dependent manner and apparently detected at concentrations of 600 and $800 \mu \mathrm{M}$. In addition, the extract has proven to have a surprising effect on the p53 (a tumor suppressor gene known to be a major regulator protein in apoptosis via performing a transcriptional activation of target genes as p21gene) for arresting cell cycle and Bax. P53 gene was found to be overexpressed in the MDA-MB231, and therefore, p53independent pathways were detected by immunoblotting. In this assay, cells were treated with the artichoke extract for $24 \mathrm{~h}$ with concentrations ranging from 200 to $800 \mu \mathrm{M}$ and the apoptotic effector agent (p21), the pro-apoptotic protein $(\mathrm{Bax})$ and the anti-apoptotic protein $(\mathrm{Bcl} 2)$ as well as p53 were detected. The p21 gene detection shows an increase in the gene expression at concentrations of 200 and $400 \mu \mathrm{M}$ without affecting the p53 expression levels. The pro-apoptotic protein Bax shows high expression at the lowest dose of artichoke extract $(200 \mu \mathrm{M})$, whereas the anti-apoptotic protein $\mathrm{Bcl} 2$ show decreased expression with increasing doses of artichoke extract [23].

In a different study, artichoke edible part components extracted with boiled methanol show a significant effect on the DNA hypermethylation which is a major factor that affects cancer growth and development via silencing of the tumor suppressor genes [124]. DNA hypermethylation was represented by the decreased 5-methylcytosine positive cell number in breast cancer cell lines MDAMB231 when treated with artichoke extract $(2.5-30 \mu \mathrm{M})$ for 10 days. This decrease in 5-methylcytosine positive cell number follows a dose-dependent behaviour [96].

Hexane was used to extract the artichoke powder prepared from the vegetative and edible parts. When the resultant three fractions were applied to the DLD1 colorectal cancer cell line, they were found to not only affect DLD1 cellular proliferation and growth, but also induce apoptotic pathways via the up- and downregulation of the pro-apoptotic gene $\mathrm{Bax}$ and the anti-apoptotic gene $\mathrm{Bcl} 2$, respectively. DNA fragmentation results carried out in this study show an increase in Bax gene expression level 5folds in the case of artichoke extracts fractions E1 (head) and E2 (vegetative part), while it found to be affected by only 2.9-fold with apigenin. The increased expression of Bax gene led to consequent increase in cell membrane permeability, hence releasing cytochrome c that promotes the mitochondrial activation of caspase-3 which in turn initiates the apoptotic pathway against DLD1 cells. On the other hand, a decrease in $\mathrm{Bcl} 2$ gene expression level was observed which means that the extracts induce programmed cell death by removing the anti-apoptotic $\mathrm{Bcl} 2$ barrier. Artichoke extracts were also found to upregulate the cyclin-dependant kinase inhibitor as well as p21 which is considered a crucial apoptotic agent as mentioned above [38].

A summary of the anticancer activities of artichoke components, expressed as the experimental $\mathrm{IC}_{50}$ values, is given in Table 3 .

\section{Factors influencing extraction efficiency Effect of solvent}

Solvent choice is the most important factor that affects the extraction process. The "like dissolves like" rule of 
Table 3 A summary of the $\mathrm{IC}_{50}$ of artichoke components obtained from different extraction methods. The cancer types treated in each study are also included

\begin{tabular}{|c|c|c|c|}
\hline Component & Cancer type & $\mathrm{IC}_{50}$ & Reference \\
\hline Catechin hydrate & Breast cancer (MCF-7) & $127.62 \mu \mathrm{g} / \mathrm{mL}$ & {$[125]$} \\
\hline EGCG & Lung cancer (H661 and H1299) & $22 \mu \mathrm{M}$ & {$[126]$} \\
\hline EGC & Lung cancer (H661 and H1299) & $22 \mu \mathrm{M}$ & {$[126]$} \\
\hline EGCG and EGC & Lung cancer (H441 and colorectal cancer HT-29) & $40-65 \mu \mathrm{M}$ & {$[126]$} \\
\hline EGCG & Liver (HepG2) & $0.5 \mathrm{mM}$ & [127] \\
\hline Epicatechin & Liver (HepG2) & $3.0 \mathrm{mM}$ & {$[127]$} \\
\hline EGCG & Breast cancer (MCF-7) & $11.2 \pm 1.4 \mu \mathrm{M}$ & {$[128]$} \\
\hline EGCG & Colorectal adenocarcinoma (HT-29) & $136.3 \pm 2.1 \mu \mathrm{M}$ & [128] \\
\hline Myricetin & Ovarian cancer (A2780 and OVCAR3) & $25 \mu \mathrm{M}$ & [129] \\
\hline Myricetin & Liver (HCC) & $25 \mu \mathrm{M}$ & [130] \\
\hline Taxifolin (TAX) & Colon (HCT116) & $\begin{array}{l}51.3 \mu \mathrm{M} \text { (for } 24 \mathrm{~h} \text { ) } \\
29.9 \mu \mathrm{M} \text { (for } 48 \mathrm{~h} \text { ) }\end{array}$ & $\begin{array}{l}{[131]} \\
{[132]}\end{array}$ \\
\hline Taxifolin (TAX) & Colon (HT29) & $\begin{array}{l}66.1 \mu \mathrm{M}(\text { for } 24 \mathrm{~h}) \\
39.0 \mu \mathrm{M}(\text { for } 48 \mathrm{~h})\end{array}$ & $\begin{array}{l}{[131]} \\
{[132]}\end{array}$ \\
\hline Taxifolin (TAX) & Skin scar cell carcinoma (SSCC) & $20 \mu \mathrm{M}$ & {$[131,132]$} \\
\hline \multirow[t]{11}{*}{ Quercetin } & Colon (CT-26) & $27.2 \pm 1.52 \mu \mathrm{M}$ & [133] \\
\hline & Prostate (LNCaP) & $21.7 \pm 2.31 \mu \mathrm{M}$ & \\
\hline & Prostate (PC3) & $36 \pm 1.98 \mu \mathrm{M}$ & \\
\hline & Pheochromocytoma (PC12) & $11.8 \pm 2.27 \mu \mathrm{M}$ & \\
\hline & Breast (MCF-7) & $13.7 \pm 2.61 \mu \mathrm{M}$ & \\
\hline & Lymphoblastic leukaemia (MOLT-4) & $2.91 \pm 0.54 \mu \mathrm{M}$ & \\
\hline & Myeloma (U266B1) & $6.13 \pm 0.73 \mu \mathrm{M}$ & \\
\hline & Lymphoma (Raji) & $3.52 \pm 0.46 \mu \mathrm{M}$ & \\
\hline & Ovary $(\mathrm{CHO})$ & $23.4 \pm 3.11 \mu \mathrm{M}$ & \\
\hline & Liver (HepG2) & $80 \mu \mathrm{M}$ & [134] \\
\hline & Squamous cell cancer (A431) & $21 \mu \mathrm{M}$ & [135] \\
\hline \multirow[t]{2}{*}{ Cyanidin } & Renal cell carcinoma (786-0) & $120.6 \mu \mathrm{M}$ & {$[136]$} \\
\hline & Renal adenocarcinoma (ACHN) & $96.96 \mu \mathrm{M}$ & {$[136]$} \\
\hline Daidzein & $\begin{array}{l}\text { Uroepithelial cell lines } \\
\text { RT4 (grade 1) } \\
\text { TSGH8301 (grade 2) } \\
\text { SCABER (grade 2) } \\
\text { BFTC-905 (grade 3) } \\
\text { T24 (grade 3) } \\
\text { J82 (grade 3) } 40 \\
\text { HT-1376 (grade 3) } 50 \\
\text { Prostate cancer } \\
\text { LNCaP and PC-3 } \\
\text { Hepatoma cells (BEL-7402) } \\
\text { Cervical (HeLa) } \\
\text { Liver (HepG-2) } \\
\text { Human osteosarcoma (MG-63) } \\
\text { Lung (A549) }\end{array}$ & $\begin{array}{l}20 \mu \mathrm{g} / \mathrm{mL} \\
40 \mu \mathrm{g} / \mathrm{mL} \\
40 \mu \mathrm{g} / \mathrm{mL} \\
30-40 \mu \mathrm{g} / \mathrm{mL} \\
40-50 \mu \mathrm{g} / \mathrm{mL} \\
40 \mu \mathrm{g} / \mathrm{mL} \\
>50 \mu \mathrm{g} / \mathrm{mL} \\
25 \mu \mathrm{g} / \mathrm{mL} \\
59.7 \pm 8.1 \mu \mathrm{M} \\
97.9 \pm 11.3 \mu \mathrm{M} \\
>100 \mu \mathrm{M} \\
>100 \mu \mathrm{M} \\
>100 \mu \mathrm{M}\end{array}$ & $\begin{array}{l}{[137]} \\
{[138]} \\
{[139]}\end{array}$ \\
\hline \multirow[t]{2}{*}{ Apigenin } & $\begin{array}{l}\text { Breast (MDA-MB-231 and MCF-7) } \\
\text { Lung (A549) } \\
\text { Hepatocellular carcinoma (SMMC-7721) } \\
\text { Esophageal carcinoma (Eca109) }\end{array}$ & $>200 \mu \mathrm{M}$ & [140] \\
\hline & Cholangiocarcinoma (HuCCA-1) & $75 \mu \mathrm{M}$ & [141] \\
\hline Luteolin & $\begin{array}{l}\text { Lung (A 549) } \\
\text { Melanoma B16 } \\
\text { T cell leukaemia cells (CCRF-HSB-2) }\end{array}$ & $\begin{array}{l}3.1 \mu \mathrm{M} \\
2.3 \mu \mathrm{M} \\
2.0 \mu \mathrm{M}\end{array}$ & $\begin{array}{l}{[135]} \\
{[135]} \\
{[135]}\end{array}$ \\
\hline
\end{tabular}


Table 3 A summary of the $\mathrm{IC}_{50}$ of artichoke components obtained from different extraction methods. The cancer types treated in each study are also included (Continued)

\begin{tabular}{|c|c|c|c|}
\hline Component & Cancer type & $I C_{50}$ & Reference \\
\hline & $\begin{array}{l}\text { Gastric cancer (TGBC11TKB cells) } \\
\text { Stomach } \\
\text { Cervix } \\
\text { Lung } \\
\text { Bladder } \\
\text { Leukaemia (HL60) } \\
\text { Squamous cell cancer (A431) } \\
\text { GLC4 (lung cancer) } \\
\text { COLO } 320 \text { (colon cancer) } \\
\text { Gastric cancer (MKN45 and BGC823) } \\
\text { Breast (MCF-7) } \\
\text { Breast (MDA-MB-231) }\end{array}$ & $\begin{array}{l}1.3 \mu \mathrm{M} \\
25 \mu \mathrm{M} \\
27 \mu \mathrm{M} \\
41 \mu \mathrm{M} \\
68 \mu \mathrm{M} \\
15 \mu \mathrm{M} \\
19 \mu \mathrm{M} \\
40.9 \mu \mathrm{M} \\
32.5 \mu \mathrm{M} \\
40 \mu \mathrm{M} \\
25 \mu \mathrm{M} \\
41.917 \mu \mathrm{M}\end{array}$ & \\
\hline Morin & Leukaemia & $250 \pm 40 \mu \mathrm{M}$ & [142] \\
\hline Hesperidin & $\begin{array}{l}\text { Hepatocellular carcinoma (HCC) } \\
\text { Leukaemia (HL60) } \\
\text { Breast (MCF-7) } \\
\text { Osteosarcoma MG-63 cells } \\
\text { Cervical (HeLa) }\end{array}$ & $\begin{array}{l}12.5 \mathrm{mM} \\
6 \mathrm{mM} \\
11 \mu \mathrm{M} \\
63.3 \mu \mathrm{M} \\
5.275 \mathrm{mM}\end{array}$ & $\begin{array}{l}{[143]} \\
{[144]} \\
{[145]} \\
{[146]}\end{array}$ \\
\hline
\end{tabular}

dissolution and the nature of the desired yield are the factors according to which the solvent can be chosen, i.e. carbohydrates and water-soluble materials must be extracted with polar solvents, while oils and lipids have to be extracted with non-polar solvents.

Methanol and ethanol are the solvents of choice when one wants to extract polyphenols with significant yields. Boiled methanol was found to produce a better yield of 3,5-DCQA, 3-CQA and 1,5-DCQA than ethanol [23]. Re-extraction of crude ethanolic extract of artichoke with ethyl acetate gives the best yield of total phenolics including caffeic acid and caffeoylquinic acid derivatives, while other solvents like $n$-butanol and ethanol itself are ranked the second and the third, respectively. In the same study, re-extraction with water has interestingly shown higher yield of total phenolics (including 3-CQA and 1,5-DCQA) than that shown by petroleum ether reextraction [62].

Polysaccharides (such as inulins) are known to be one of the major components found in artichoke plant as well as any other plant tissues. Water is a perfect solvent in the extraction of plant polysaccharides, and it is more favourable than polar organic solvents such as ethanol. Using hot water at different temperatures shows impressive results in extraction of inulin, which is the most common polysaccharide in artichoke, as the yield of inulin extracted with hot water reaches $60 \%$ of the whole polysaccharides content [74], while using ethanol leads to extraction of only $1.7 \%$ of the total polysaccharides [42]. According to the above-mentioned studies, caution should be taken while selecting a solvent for extracting certain artichoke components for subsequent use in cancer treatment.

\section{Effect of time and temperature}

It is intuitive that extending the time required for solvent extraction results in increasing the yield of the extracted components. Similarly, high temperature is supposed to facilitate the dissolution of artichoke plant components in the used solvent and then it results in a more efficient extraction. In one of the studies, using hot water of different temperatures and different time intervals showed variations in the obtained yield of inulin. When $100{ }^{\circ} \mathrm{C}$ water was used in the extraction of inulin from artichoke tubers for $20 \mathrm{~min}$, the highest yield of inulin (60\%) was obtained. However, the yield was decreased when the same solvent was applied for 10 or $30 \mathrm{~min}$. On the other hand, applying 70 and $80{ }^{\circ} \mathrm{C}$ shows a little bit lower inulin yield. An impressive inulin yield higher than $40 \%$ was obtained at $70{ }^{\circ} \mathrm{C}$ when the tubers were extracted for $30 \mathrm{~min}$. Therefore, it was found in this study that applying a temperature of $80{ }^{\circ} \mathrm{C}$ for 20 min is the best way to obtain the highest inulin yield from artichoke plant [74].

Another study used to extract the inulin and inositols from artichoke dried bracts using 2 aqueous methods: MAE and PLE with application of temperature range of $40-120^{\circ} \mathrm{C}$ and time range of $3-30 \mathrm{~min}$ in both. The results show that the MAE is the best method to obtain the best yield of inositol which was $11.6 \mathrm{mg} / \mathrm{g}$ of dry sample vs $7.6 \mathrm{mg} / \mathrm{g}$ obtained from the PLE method with the application of relatively high temperature $\left(65-70{ }^{\circ} \mathrm{C}\right)$ for a short time (3 min). In contrary, using the PLE method at high temperature $\left(65-70{ }^{\circ} \mathrm{C}\right)$ for $26.7 \mathrm{~min}$ was found to be the best conditions to obtain the highest yield of inulin which was $185.4 \mathrm{mg} / \mathrm{g}$ of dry sample vs $96.4 \mathrm{mg} / \mathrm{g}$ in the case of MAE [79]. 


\section{Conclusion}

In this review, the work reported on the use of artichoke extracts as antitumor agents was summarized and discussed. The previous trials show that artichoke contains some active substances (e.g. polyphenols and flavonoids) that possess excellent anticancer activities. The conditions applied in the solvent extraction method are key factors that interestingly affect the composition as well as the yield of the obtained extract. Moreover, other factors that may influence the extraction efficiency such as the temperature of the extracting solvent and the extraction time have been discussed. Relying on the previous work collected in the current review article, it will be easy for researchers interested in treating cancer with artichoke (and similar plants) extract to apply the most suitable extraction conditions. Researchers dealing with artichoke extracts for cancer treatment should follow an accurate analytical protocol (such as gas chromatography/mass spectrometry, GC/MS) for the components they obtain from the extraction processes. No doubt that this analytical step will provide information about the components present in the extract and their corresponding yields, leading to easier interpretation of the anticancer results and correct unearthing of the mechanisms underlying their effects on cancer cell lines. Finally, this area of cancer treatment is very hot and immature, meaning that there will be more research to be done in the near future especially in the methods of separation, analysis and delivery of artichoke extract components to treat different types of cancers.

\section{Abbreviations \\ 3,5-DCQAME: Dicaffeoylquinic acid methyl ether; AE: Artichoke extract; AIF: Apoptotic-inducing factor; APC: Adenomatous polyposis coli; API: Apigenin; ASE: Accelerator solvent extractor; CBP: Core basal phenotype; ChA: Chlorogenic acid; CIMP: Isolated methylator phenotype; CIN: Chromosomal instability; CK5/6: Cytokeratin protein; CQA: Caffeoylquinic acid; CRC: Colorectal cancer; DCQA: Dicaffeoylquinic acid; DER: Dry extract ratio; DISCs: Death-inducing-signals complexes; DPPH: 2,2-Diphenyl-1- picrylhydrazyl; EA: Ethyl acetate; EC: Epicatechin; EGC: Epigallocatechin; EGCG: Epigallocatechin-3-gallate; ER: Oestrogen receptor; FADD: Fas- associated death domain; FRAP: Ferric reducing ability assay; FW: Fresh weight; GSH: Glutathione; HBV: Hepatitis B virus; HCC: Hepatocellular carcinoma; HER2: Human epidermal growth factor receptor 2; HMC: Mesothelial cells; HSCs: Haematopoietic stem cells; MAE: Microwave- assisted extraction; MGMT: 0-6-Methylguanine-DNA methyltransferase; MLH1: MutL homolog 1; MMR: DNA-mismatch repair; MSI: Microsatellite instability; PARP-1: Poly-ADP ribose protein-1; PLE: Pressurized liquid extraction; RNS: Reactive nitrogen species; ROS: Reactive oxygen species; RP: Progesterone receptor; SLs: Sesquiterpene lactones; TAX: Taxifolin; TEAC: Troxol-equivalent antioxidant capacity assay; TFC: Total flavonoid compounds; TPC: Total phenolic compounds}

\section{Acknowledgements}

The authors are grateful to Cairo University for providing infrastructural support by way of online resources required for this review.

\section{Authors' contributions}

HHS carried out the literature review and participated in the writing process. ASA suggested the review article's topic and participated in writing, revision and editing of the manuscript. NAM and $A B$ participated in writing and editing. All authors have read and approved the manuscript.
Funding

Not applicable

Availability of data and materials

Data and materials are available upon request.

Ethics approval and consent to participate

Not applicable

\section{Consent for publication}

Not applicable

\section{Competing interests}

The authors declare that they have no competing interests.

\section{Author details}

${ }^{1}$ Zoology Department, Faculty of Science, Cairo University, Giza 12613, Egypt. ${ }^{2}$ Pharmaceutical Chemistry Department, National Organization for Drug Control and Research (NODCAR), Giza, Egypt. ${ }^{3}$ Faculty of Oral and Dental Medicine, Future University in Egypt (FUE), New Cairo, Egypt.

Received: 15 November 2019 Accepted: 31 August 2020

Published online: 31 October 2020

\section{References}

1. Malumbres M, Barbacid M (2009) Cell cycle, CDKs and cancer: a changing paradigm Marcos. Nat Rev Cancer 9:153-166. https://doi.org/10.1038/ $\operatorname{nrc2602}$

2. Witsch E, Sela M, Yarden $Y$ (2010) Roles for growth factors in cancer progression. Physiology 25:85-101. https://doi.org/10.1152/physiol. 00045.2009

3. Fouad YA, Aanei C (2017) Revisiting the hallmarks of cancer. An Venez Nutr 7:1016-1036. https://doi.org/10.1017/CH09781139028387.011

4. Portis E, Acquadro A, Comino C et al (2005) Genetic structure of island populations of wild cardoon [Cynara cardunculus L. var. sylvestris (Lamk) Fiori] detected by AFLPs and SSRs. Plant Sci 169:199-210. https://doi.org/10. 1016/.j.plantsci.2005.03.014

5. Gominho J, Curt MD, Lourenço A et al (2018) Cynara cardunculus L. as a biomass and multi-purpose crop: a review of 30 years of research. Biomass and Bioenergy 109:257-275. https://doi.org/10.1016/j.biombioe.2018.01.001

6. Ceccarelli N, Curadi M, Picciarelli P et al (2010) Globe artichoke as a functional food. Med J Nutrition Metab 3:197-201. https://doi.org/10.1007/ s12349-010-0021-z

7. Karasin N, Tolan V, Hasimi N, Demirci O (2019) Investigation of genotoxic, antimicrobial and antioxidant activities of leaf and flower extracts of Cynara syriacaBoiss. J Agric Sci 25:346-353.

8. Biel W (2019) Proximate composition, minerals and antioxidant activity of artichoke leaf extracts

9. Hanahan D, Weinberg RA (2011) Hallmarks of cancer: the next generation. Cell 144:646-674. https://doi.org/10.1016/j.cell.2011.02.013

10. Hanahan D, Weinberg RA (2000) The hallmarks of cancer. Netherlands Hear J 100:57-70. https://doi.org/10.1007/BF03091804

11. Wu S, Wu M, Zhang C et al (2014) Research progress of natural antioxidants in foods for the treatment of diseases. Food Sci Hum Wellness 3:110-116. https://doi.org/10.1016/j.fshw.2014.11.002

12. Petropoulos SA, Pereira C, Ntatsi G et al (2018) Nutritional value and chemical composition of Greek artichoke genotypes. Food Chem 267:296302. https://doi.org/10.1016/j.foodchem.2017.01.159

13. Capacity A (2019) Phenolic composition of artichoke waste and its antioxidant capacity on differentiated Caco-2 cells

14. Petropoulos S, Fernandes Â, Pereira C et al (2019) Bioactivities, chemical composition and nutritional value of Cynara cardunculus L. seeds. 289:404412. https://doi.org/10.1016/j.foodchem.2019.03.066

15. Yang M, Ma Y, Wang Z et al (2020) Phenolic constituents, antioxidant and cytoprotective activities of crude extract and fractions from cultivated artichoke inflorescence. Ind Crops Prod 143:111433. https://doi.org/10.1016/ j.indcrop.2019.05.082

16. Wang HC, Brumaghim JL (2011) Polyphenol compounds as antioxidants for disease prevention: reactive oxygen species scavenging, enzyme regulation, and metal chelation mechanisms in E. coli and human cells. ACS Symp Ser 1083:99-175. https://doi.org/10.1021/bk-2011-1083.ch005 
17. Gump F (2006) Breast cancer treatment. J Am Coll Surg 206:1240. https:// doi.org/10.1016/j.jamcollsurg.2008.01.029

18. Yang XR, Chang-Claude J, Goode EL et al (2011) Associations of breast cancer risk factors with tumor subtypes: a pooled analysis from the breast cancer association consortium studies. J Natl Cancer Inst 103:250-263. https://doi.org/10.1093/inci/dja526

19. Anderson WF, Chu KC, Chang S, Sherman ME (2004) Comparison of agespecific incidence rate patterns for different histopathologic types of breast carcinoma. Cancer Epidemiol Biomarkers Prev 13:1128-1135

20. Nielsen TO, Hsu FD, Jensen $\mathrm{K}$ et al (2004) Immunohistochemical and clinical characterization of the basal-like subtype of invasive breast carcinoma. Clin Cancer Res 10:5367-5374. https://doi.org/10.1158/1078-0432.CCR-04-0220

21. Demicheli R, Bonadonna G, Greco M, et al (2006) Comment to Anderson WF, Jatoi I, Devesa SS: Distinct breast cancer incidence and prognostic patterns in the NCl's SEER Program: suggesting a possible link between etiology and outcome. Breast Cancer Res Treat 90:127-137, 2005 [2]. Breast Cancer Res Treat 97:341-343 . doi: https://doi.org/10. 1007/s10549-005-9128-1

22. Vígh S, Zsvér-Vadas Z, Pribac C et al (2016) Artichoke (Cynara scolymus L.) extracts are showing concentration-dependent hormetic and cytotoxic effects on breast cancer cell lines. Stud Univ Vasile Goldis Arad. Ser Stiint Vietii 26:423-433

23. Mileo AM, Di Venere D, Linsalata V et al (2012) Artichoke polyphenols induce apoptosis and decrease the invasive potential of the human breast cancer cell line MDA-MB231. J Cell Physiol 227:3301-3309. https://doi.org/ 10.1002/jcp.24029

24. Tunissiolli NM, Castanhole-Nunes MMU, Biselli-Chicote PM et al (2017) Hepatocellular carcinoma: a comprehensive review of biomarkers, Clinical Aspects, and Therapy. Asian Pac J Cancer Prev 18:863-872. https://doi.org/ 10.22034/APJCP.2017.18.4.863

25. Waller LP, Deshpande V, Pyrsopoulos N (2015) Hepatocellular carcinoma: a comprehensive review. World J Hepatol 7:2648-2663. https://doi.org/10. 4254/wjh.v7.i26.2648

26. Kew MC (1998) Hepatitis viruses and hepatocellular carcinoma. Cancer Inflamm Mech Chem Biol Clin Asp 149:257-262. https://doi.org/10.1002/ 9781118826621.ch13

27. Block TM, Mehta AS, Fimmel CJ, Jordan R (2003) Molecular viral oncology of hepatocellular carcinoma. Oncogene 22:5093-5107. https://doi.org/10.1038/ sj.onc. 1206557

28. Hamid AS, Tesfamariam SG, Zhang Y, Zhang ZG (2013) Aflatoxin B1-induced hepatocellular carcinoma in developing countries: geographical distribution, mechanism of action and prevention (Review). Oncol Lett 5:1087-1092. https://doi.org/10.3892/ol.2013.1169

29. El AM, Hussein R, Abdel A et al (2018) Artichoke edible parts are hepatoprotective as commercial leaf preparation. Rev Bras Farmacogn 28: 165-178. https://doi.org/10.1016/j.bjp.2018.01.002

30. Al-Radadi NS (2018) Artichoke (Cynara scolymus L.) mediated rapid analysis of silver nanoparticles and their utilisation on the cancer cell treatments. doi: https://doi.org/10.1166/jctn.2018.7317

31. Tang X, Wei R, Deng A, Lei T (2017) Protective effects of ethanolic extracts from artichoke, an edible herbal medicine, against acute alcohol-induced liver injury in mice. https://doi.org/10.3390/nu9091000

32. Miccadei S, Di Venere D, Cardinali A et al (2008) Antioxidative and apoptotic properties of polyphenolic extracts from edible part of artichoke (Cynara scolymus L.) on cultured rat hepatocytes and on human hepatoma cells. Nutr Cancer 60:276-283. https://doi.org/10.1080/ 01635580801891583

33. Gaafar AA, Salama ZA, El Baz FK (2013) Antioxidant and antiproliferative effects on human liver HePG2 epithelial cells from artichoke (Cynara scolymus L.) By-Products. J Nat Sci Res www 3:2225-2921. https://doi.org/10. 1017/s0016672305007573

34. Tariq K, Ghias K (2016) Colorectal cancer carcinogenesis: a review of mechanisms of carcinogenesis. Cancer Biol Med 13:120-135. https://doi.org/ 10.28092/j.issn.2095-3941.2015.0103

35. Fearon EF, Vogelstein B (1990) A genetic model for colorectal tumorigenesis. Cell 61:759-767

36. Wyman R (1977) CpG island methylator phenotype underlies sporadic microsatellite instability and is tightly associated with BRAF mutation in colorectal cancer. SMPTE J 86:486-487. https://doi.org/10.1038/ng1834

37. Markowitz SD, Bertagnolli MM (2009) Molecular basis of colorectal cancer. N Engl J Med 361:1-19
38. Simsek EN, Uysal T (2013) In vitro investigation of cytotoxic and apoptotic effects of Cynara L. species in colorectal cancer cells. Asian Pacific J Cancer Prev 14:6791-6795. https://doi.org/10.7314/APJCP.2013.14.11.6791

39. Polychronakis I, Dounias G, Makropoulos V et al (2013) Work-related leukemia: a systematic review. J Occup Med Toxicol 8:1-16. https://doi.org/ 10.1186/1745-6673-8-14

40. Muthiah K, Suja S (2017) Growth inhibitory effect of ethyl acetate-soluble fraction of Cynara cardunculus I. in leukemia cells involves cell cycle arrest, cytochrome c release and activation of caspases. Transform Bus Econ 16:8599. https://doi.org/10.1002/ptr

41. Carbone M, Ly BH, Dodson RF et al (2012) Malignant mesothelioma: facts, myths, and hypotheses. J Cell Physiol 227:44-58. https://doi.org/10.1002/jcp. 22724

42. Pulito C, Mori F, Sacconi A, et al (2015) Cynara scolymus affects malignant pleural mesothelioma by promoting apoptosis and restraining invasion. Oncotarget 6:18134-18150. doi: https://doi.org/10.18632/oncotarget.4017

43. Kusirisin W. Srichairatanakool S, Lerttrakarnnon P et al (2009) Antioxidative activity, polyphenolic content and anti-glycation effect of some Thai medicinal plants traditionally used in diabetic patients. Med Chem 5:139-147

44. Obrenovich ME, Nair NG, Beyaz A et al (2010) The role of polyphenolic antioxidants in health, disease, and aging. Rejuvenation Res 13:631-643. https://doi.org/10.1089/rej.2010.1043

45. Ksouri R, Megdiche W, Falleh $\mathrm{H}$ et al (2008) Influence of biological, environmental and technical factors on phenolic content and antioxidant activities of Tunisian halophytes. C R Biol 331:865-873. https://doi.org/10. 1016/..crvi.2008.07.024

46. Petropoulos SA, Pereira C, Barros L (2017) Leaf parts from Greek artichoke genotypes as a good source of bioactive compounds and antioxidants. 2022-2029. doi: https://doi.org/10.1039/c7fo00356k

47. Andreassi MG (2008) DNA damage, vascular senescence and atherosclerosis. I Mol Med (Berl) 86:1033-1043. https://doi.org/10.1007/s00109-008-0358-7

48. Mena S, Ortega A, Estrela JM (2009) Oxidative stress in environmentalinduced carcinogenesis. Mutat Res 674:36-44. https://doi.org/10.1016/j. mrgentox.2008.09.017

49. Manach C, Mazur A, Scalbert A (2005) Polyphenols and prevention of cardiovascular diseases. Curr Opin Lipidol 16:77-84

50. Kowluru RA, Kanwar M (2007) Effects of curcumin on retinal oxidative stress and inflammation in diabetes. Nutr Metab (Lond) 4:1-8. https://doi.org/10. 1186/1743-7075-4-8

51. Koren E, Kohen R, Ginsburg I (2010) Polyphenols enhance total oxidantscavenging capacities of human blood by binding to red blood cells. Exp Biol Med 235:689-699. https://doi.org/10.1258/ebm.2010.009370

52. Smirnova GV, Samoylova ZY, Muzyka NG, Oktyabrsky ON (2009) Influence of polyphenols on Escherichia coli resistance to oxidative stress. Free Radic Biol Med 46:759-768

53. Jomova K, Vondrakova D, Lawson M, Valko M (2010) Metals, oxidative stress and neurodegenerative disorders. Mol Cell Biochem 345:91-104. https://doi, org/10.1007/s11010-010-0563-x

54. Ramprasath VR, Jones PJH (2010) Anti-atherogenic effects of resveratrol. Eur J Clin Nutr 64:660-668. https://doi.org/10.1038/ejcn.2010.77

55. Okawa M, Kinjo J, Nohara T, Ono M (2001) DPPH (1,1-diphenyl-2picrylhydrazyl) radical scavenging activity of flavonoids obtained from some medicinal plants. Biol Pharm Bull 24:1202-1205

56. Yanagimoto K, Ochi H, Lee K-G, Shibamoto T (2004) Antioxidative activities of fractions obtained from brewed coffee. J Agric Food Chem 52:592-596. https://doi.org/10.1021/jf030317t

57. Salekzamani S (2019) The antioxidant activity of artichoke (Cynara scolymus): a systematic review and meta-analysis of animal studies. 55-71. doi: https:// doi.org/10.1002/ptr.6213

58. Elgarawany GE, Abdou AG, Taie DM (2020) Hepatoprotective effect of artichoke leaf extracts in comparison with silymarin on acetaminopheninduced hepatotoxicity in mice. J Immunoass Immunochem 41:84-96. https://doi.org/10.1080/15321819.2019.1692029

59. Rezazadeh K, Rahmati M, Mohammadnejad L (2018) Effects of artichoke leaf extract supplementation on metabolic parameters in women with metabolic syndrome: influence of TCF7L2-rs7903146 and FTO-rs9939609 polymorphisms. Phyther Res:84-93. https://doi.org/10.1002/ptr.5951

60. Rezazadeh K, Rezazadeh F, Ebrahimi-mameghani M (2018) European Journal of Integrative Medicine The effect of artichoke leaf extract supplementation on lipid and CETP response in metabolic syndrome with respect to Taq 1B 
CETP polymorphism: a randomized placebo-controlled clinical trial. Eur J Integr Med 17:112-118. https://doi.org/10.1016/j.eujim.2017.12.008

61. Rezazadeh K, Asghari-jafarabadi M (2019) Advances in Integrative Medicine. The interaction of FTO-rs9939609 polymorphism with artichoke leaf extract effects on cardiometabolic risk factors in hypertriglyceridemia: a randomized clinical trial. Biochem Pharmacol 6:104-109. https://doi.org/10.1016/j.aimed. 2018.08 .006

62. Yuan X, Gao M, Xiao H et al (2012) Free radical scavenging activities and bioactive substances of Jerusalem artichoke (Helianthus tuberosus L.) leaves. Food Chem 133:10-14. https://doi.org/10.1016/j.foodchem.2011.09.071

63. Di Venere D, Linsalata $V$, Pace B et al (2005) Polyphenol and inulin content in a collection of artichoke. Acta Hortic 681:453-460. https://doi.org/10. 17660/ActaHortic.2005.681.63

64. Sisto A, Luongo D, Treppiccione L et al (2016) Effect of Lactobacillus paracasei culture filtrates and artichoke polyphenols on cytokine production by dendritic cells. Nutrients 8 . https://doi.org/10.3390/nu8100635

65. Mohamed Abdel Magied M, EL DHS, Mohamed Zaki S, EL MSR (2016) Artichoke (Cynara scolymus L.) leaves and heads extracts as hypoglycemic and hypocholesterolemic in rats. J Food Nutr Res 4:60-68. https://doi.org/ 10.12691/jfnr-4-1-10

66. Yuan X, Yang Q (2017) Simultaneous quantitative determination of 11 sesquiterpene lactones in Jerusalem artichoke (Helianthus tuberosus L.) leaves by ultra high performance liquid chromatography with quadrupole time-of-flight mass spectrometry. J Sep Sci 40:1457-1464. https://doi.org/10. 1002/jssc.201601135

67. Ko H, Bae J, Kim M et al (2019) Industrial crops \& products microbial production of difructose anhydride III from Jerusalem artichoke tuber powder by recombinant yeast Saccharomyces cerevisiae and Kluyveromyces marxianus. Ind Crop Prod 135:99-106. https://doi.org/10.1016/j.indcrop.2019. 04.026

68. Lavecchia R, Maffei G, Paccassoni F et al (2019) Artichoke waste as a source of phenolic antioxidants and bioenergy. Waste and Biomass Valorization 10: 2975-2984. https://doi.org/10.1007/s12649-018-0305-y

69. Capotorto I, Innamorato V, Cefola M et al (2020) Postharvest biology and technology high $\mathrm{CO}_{2}$ short-term treatment to preserve quality and volatiles profile of fresh-cut artichokes during cold storage. Postharvest Biol Technol 160:111056. https://doi.org/10.1016/j.postharvbio.2019.111056

70. Essid I (2020) Use of pomegranate peel and artichoke leaf extracts to improve the quality of marinated sardine (Sardinella aurita) fillets. J Food Sci Technol 57:713-722. https://doi.org/10.1007/s13197-019-04104-x

71. Bueno-Gavilá E, Abellán A, Bermejo MS et al (2020) Characterization of proteolytic activity of artichoke (Cynara scolymus L.) flower extracts on bovine casein to obtain bioactive peptides. Animals 10:914. https://doi.org/ 10.3390/ani10050914

72. dos Santos LD, Garbin de Almeida M, Teixeira C et al (2018) Biochemical and physiological parameters in rats fed with high-fat diet: the protective effect of chronic treatment with purple grape juice (Bordo variety). Beverages 4:100. https://doi.org/10.3390/beverages4040100

73. Jacociunas LV, Dihl RR, Lehmann M et al (2014) Effects of artichoke (Cynara scolymus) leaf and bloom head extracts on chemically induced DNA lesions in Drosophila melanogaster. Genet Mol Biol 37:93-104. https://doi.org/10. 1590/S1415-47572014000100015

74. orn SB, Nuchadomrong S, Jogloy S et al (2015) Preparation of inulin powder from Jerusalem artichoke (Helianthus tuberosus L.) tuber. Plant Foods Hum Nutr 70:221-226. https://doi.org/10.1007/s11130-015-0480-y

75. Abou-arab AA, Talaat HA, Abu-salem FM (2011) Physico-chemical properties of inulin produced from Jerusalem artichoke tubers on bench and pilot plant scale. 5:1297-1309

76. Li H, Zhu H, Qiao J et al (2012) Optimization of the main liming process for inulin crude extract from Jerusalem artichoke tubers. Front Chem Sci Eng 6: 348-355. https://doi.org/10.1007/s11705-012-1295-0

77. Baldini M, Danuso F, Turi M, Vannozzi GP (2004) Evaluation of new clones of Jerusalem artichoke (Helianthus tuberosus L.) for inulin and sugar yield from stalks and tubers. Ind Crops Prod 19:25-40. https://doi.org/10.1016/S09266690(03)00078-5

78. Terkmane N, Krea M, Moulai-Mostefa N (2016) Optimisation of inulin extraction from globe artichoke (Cynara cardunculus L. subsp. Scolymus (L.) Hegi.) by electromagnetic induction heating process. Int J Food Sci Technol 51:1997-2008. https://doi.org/10.1111/ijfs.13167

79. Ruiz-aceituno L, García-sarrió MJ, Alonso-rodriguez B et al (2016) Extraction of bioactive carbohydrates from artichoke (Cynara scolymus L.) external bracts using microwave assisted extraction and pressurized liquid extraction. Food Chem 196:1156-1162. https://doi.org/10.1016/j.foodchem.2015.10.046

80. Fratianni F, Pepe R, Nazzaro F (2014) Polyphenol composition, antioxidant, antimicrobial and quorum quenching activity of the "Carciofo di Montoro" (Cynara cardunculus var. scolymus ) Global artichoke of the Campania Region, Southern Italy. Food Nutr Sci 5:2053-2062. https://doi.org/10.4236/ fns.2014.521217

81. Spring O (1991) Sesquiterpene lactones from Helianthus tuberosus. Phytochemistry 30:519-522. https://doi.org/10.1016/0031-9422(91)83718-Z

82. Taha HS, Abd El-Kawy AM, Fathalla MAEK (2012) A new approach for achievement of inulin accumulation in suspension cultures of Jerusalem artichoke (Helianthus tuberosus) using biotic elicitors. J Genet Eng Biotechnol 10:33-38. https://doi.org/10.1016/j.jgeb.2012.02.002

83. Maraldi T (2013) Natural compounds as modulators of NADPH oxidases. Oxid Med Cell Longev 2013: . doi: https://doi.org/10.1155/2013/271602

84. Tan AC, Konczak I, Sze DMY, Ramzan I (2011) Molecular pathways for cancer chemoprevention by dietary phytochemicals. Nutr Cancer 63:495-505. https://doi.org/10.1080/01635581.2011.538953

85. Mileo AM (2016) Miccadei S (2016) Polyphenols as modulator of oxidative stress in cancer disease: new therapeutic strategies. Oxid Med Cell Longev. https://doi.org/10.1155/2016/6475624

86. Kubatka P, Kapinová A, Kello M et al (2016) Fruit peel polyphenols demonstrate substantial anti-tumour effects in the model of breast cancer. Eur J Nutr 55:955-965. https://doi.org/10.1007/s00394-015-0910-5

87. Ren W, Qiao Z, Wang $\mathrm{H}$ et al (2003) Flavonoids: promising anticancer agents. Med Res Rev 23:519-534. https://doi.org/10.1002/med.10033

88. Jeanmonod DJ, Rebecca SK et al (2018) We are IntechOpen, the world's leading publisher of open access books built by scientists, for scientists top $1 \%$ control of a proportional hydraulic system. Intech open:287-303. https:// doi.org/10.5772/32009

89. Belkaid A, Currie JC, Desgagnés J, Annabi B (2006) The chemopreventive properties of chlorogenic acid reveal a potential new role for the microsomal glucose-6-phosphate translocase in brain tumor progression. Cancer Cell Int 6:1-12. https://doi.org/10.1186/1475-2867-6-7

90. Brglez Mojzer E, Knez Hrnčič M, Škerget M et al (2016) Polyphenols: extraction methods, antioxidative action, bioavailability and anticarcinogenic effects. Molecules 21. https://doi.org/10.3390/molecules21070901

91. Tungmunnithum D, Thongboonyou A, Pholboon A, Yangsabai A (2018) Flavonoids and other phenolic compounds from medicinal plants for pharmaceutical and medical aspects: an overview. Medicines 5:93. https:// doi.org/10.3390/medicines5030093

92. Yan Y, Li J, Han J et al (2015) Chlorogenic acid enhances the effects of 5fluorouracil in human hepatocellular carcinoma cells through the inhibition of extracellular signal-regulated kinases. Anticancer Drugs 26:540-546. https://doi.org/10.1097/CAD.0000000000000218

93. Losada-Echeberría M, Herranz-López M, Micol V, Barrajón-Catalán E (2017) Polyphenols as promising drugs against main breast cancer signatures. Antioxidants 6:88. https://doi.org/10.1016/j.engfailanal.2013.05.012

94. Moon A (2017) Anti-cancer therapy: chlorogenic acid, gallic acid and ellagic acid in synergism. IOSR J Pharm Biol Sci 12:48-52. https://doi.org/10.9790/ 3008-1203064852

95. Chowdhury AR, Sharma S, Mandal S et al (2002) Luteolin, an emerging anticancer flavonoid, poisons eukaryotic DNA topoisomerase I. Biochem J 366: 653-661. https://doi.org/10.1042/bj20020098

96. Mileo AM, Di Venere D, Abbruzzese C, Miccadei S (2015) Long term exposure to polyphenols of artichoke (Cynara scolymus L.) exerts induction of senescence driven growth arrest in the MDA-MB231 human breast cancer cell line. Oxid Med Cell Longev 1-11 . doi: https://doi.org/10.1155/ 2015/363827

97. Kaufmann SH, Earnshaw WC (2000) Induction of apoptosis by cancer chemotherapy. Exp Cell Res 256:42-49. https://doi.org/10.1006/excr.2000. 4838

98. ODIN L, TORNBLOM N (1959) Studies on the chemical composition of glomeruli isolated from human kidneys with Kimmelstiel-Wilson lesions. Acta Soc Med Ups 64:313-321. https://doi.org/10.1093/carcin/21.3.485

99. Hengartner MO (2000) The biochemistry of apoptosis Michael. 407:770-776. https://doi.org/10.1038/35037710

100. Leppa S, Bohmann D (1999) Diverse functions of JNK signaling and c-Jun in stress response and apoptosis. 18:6158-6162

101. Davis RJ (2000) Signal Transduction by the JNK group of MAP kinases. Cell 103:239-252. https://doi.org/10.1016/S0092-8674(00)00116-1 
102. Debatin K (1999) The role of CD95 system in chemotherapy. 2:85-90

103. Mayo MW, Baldwin AS (2000) The transcription factor NF-kB: control of oncogenesis and cancer therapy resistance. Biochim Biophys Acta-Rev Cancer 1470:55-62. https://doi.org/10.1016/S0304-419X(00)00002-0

104. Slee EA, Adrain C, Martin SJ (1999) Serial killers: ordering caspase activation events in apoptosis. Cell Death Differ 6:1067-1074. https://doi.org/10.1038/ sj.cdd. 4400601

105. Degen WGJ, Pruijn GJM, Raats JMH, Van Venrooij WJ (2000) Caspasedependent cleavage of nucleic acids. Cell Death Differ 7:616-627. https:// doi.org/10.1038/sj.cdd.4400672

106. Los M, Wesselborg S, Schulze-Osthoff K (1999) The role of caspases in development, immunity, and apoptotic signal transduction: lessons from knockout mice. Immunity 10:629-639. https://doi.org/10.1016/S10747613(00)80062-X

107. Utz PJ, Anderson P (2000) Life and death decisions: regulation of apoptosis by proteolysis of signaling molecules. Cell Death Differ 7:589-602. https:// doi.org/10.1038/sj.cdd.4400696

108. Earnshaw WC, Martins LM, Kaufmann SH (1999) Mammalian caspases: structure, activation, substrates, and functions during apoptosis. Annu Rev Biochem 68:383-424. https://doi.org/10.1146/annurev.biochem.68.1.383

109. Walczak H, Krammer PH (2000) The CD95 (APO-1/Fas) and the TRAIL (APO2L) apoptosis systems. Exp Cell Res 256:58-66. https://doi.org/10.1006/excr. 2000.4840

110. Schulze-Osthoff K, Ferrari D, Los M et al (1998) Apoptosis signaling by death receptors. Eur J Biochem 254:439-459. https://doi.org/10.1046/j.1432-1327. 1998.2540439.x

111. Krammer PH (2000) the immune system B cells. Nature 407:789-795

112. de Louwa. J., de Vente J, Steinbusch HP HW., et al (2000) Articulo especial medicina mitocondrial muerte celular y/o apoptosis. Cell 102:124-133 . doi: https://doi.org/10.1016/S0896-6273(00)80282-2

113. Du C, Fang M, Li Y et al (2000) SMAC_IAP.pdf. 102:33-42. https://doi.org/10. 1016/S0092-8674(00)00008-8

114. Suzuki $Y$, Imai $Y$, Nakayama $H$ et al (2001) A serine protease, $H \operatorname{tr} A 2$, is released from the mitochondria and interacts with XIAP, inducing cell death. Mol Cell 8:613-621. https://doi.org/10.1016/S1097-2765(01)00341-0

115. Jean-Claude M, Douglas RG (2001) Breaking the mitochondrial barrier. Nat Rev Mol Cell Biol 2:63-67

116. Kroemer G (2001) B709 mitochondrial control of cell death. ScientificWorldJournal 1:1-2. https://doi.org/10.1100/tsw.2001.167

117. Costantini $P$, Jacotot $E$, Decaudin D, Kroemer G (2000) Mitochondrion as a novel target of anticancer chemotherapy. JNCI J Natl Cancer Inst 92:10421053. https://doi.org/10.1093/jnci/92.13.1042

118. Bratton SB, MacFarlane M, Cain K, Cohen GM (2000) Protein complexes activate distinct caspase cascades in death receptor and stress-induced apoptosis. Exp Cell Res 256:27-33. https://doi.org/10.1006/excr.2000.4835

119. Roy S, Nicholson DW (2000) Cross-talk in cell death signaling. J Exp Med 192:F21-F26. https://doi.org/10.1084/jem.192.8.F21

120. Hirad AH, Bahkali AH, Khiyami MA et al (2013) Antimicrobial activity of marine microorganisms isolated from the coast of the Arabian Gulf. J Pure Appl Microbiol 7:1159-1164. https://doi.org/10.1007/s00262-003-0474-8

121. Chaitanya GV, Alexander JS, Babu PP (2010) PARP-1 cleavage fragments: signatures of cell-death proteases in neurodegeneration. Cell Commun Signal 8:1-11. https://doi.org/10.1186/1478-811X-8-31

122. Tewari M, Quan LT, O'Rourke K et al (1995) Yama/CPP32ß, a mammalian homolog of CED-3, is a CrmA-inhibitable protease that cleaves the death substrate poly(ADP-ribose) polymerase. Cell 81:801-809. https://doi.org/10. 1016/0092-8674(95)90541-3

123. Kaufmann SH, Desnoyers S, Ottaviano Y et al (1993) Specific proteolytic cleavage of poly (ADP-ribose) polymerase: an early marker of chemotherapy-induced apoptosis specific proteolytic cleavage of poly (ADP-ribose) polymerase: an early marker of chemotherapy-induced apoptosis. Recherche 53:3976-3985. https://doi.org/10.1074/jbc.274.33.22932

124. Kristiansen S, Nielsen D, Sölétormos G (2014) Methylated DNA for monitoring tumor growth and regression: how do we get there? Crit Rev Clin Lab Sci 51:149-159. https://doi.org/10.3109/10408363.2014.893279

125. Alshatwi AA (2010) Catechin hydrate suppresses MCF-7 proliferation through TP53/caspase-mediated apoptosis. J Exp Clin Cancer Res 29:167. https://doi.org/10.1186/1756-9966-29-167

126. Rudolfova P, Hanusova V, Skalova L et al (2014) Effect of selected catechins on doxorubicin antiproliferative efficacy and hepatotoxicity in vitro. Acta Pharm 64:199-209. https://doi.org/10.2478/acph-20140018
127. Khiewkamrop P, Phunsomboon P, Richert L, Pekthong D (2018) Epistructured catechins, EGCG and EC facilitate apoptosis induction through targeting de novo lipogenesis pathway in HepG2 cells. Cancer Cell Int:1-13. https://doi.org/10.1186/s12935-018-0539-6

128. Terzi YK, Kaya ÖÖ, Işeri ÖD et al (2015) Epigallocatechin 3-gallate applications on HT-29 and MCF-7 cell lines and evaluation of tumor suppressor gene methylation. 698-704. https://doi.org/10.3906/biy-1412-82

129. AIWEN Z, YAQ C, LQIN Z, JGUO F (2017) Myricetin induces apoptosis and enhances chemosensitivity in ovarian cancer cells:4974-4978. https://doi. org/10.3892/ol.2017.6031

130. Seydi E, Rasekh HR, Salimi A et al (2016) Myricetin selectively induces apoptosis on cancerous hepatocytes by directly targeting their mitochondria. 249-258. https://doi.org/10.1111/bcpt.12572

131. Razak S, Afsar T, Ullah A, et al (2018) Taxifolin, a natural flavonoid interacts with cell cycle regulators causes cell cycle arrest and causes tumor regression by activating Wnt/ $\beta$-catenin signaling pathway. 1-18

132. Zhou W, Liu Z, Wang M, et al (2019) Taxifolin inhibits the development of scar cell carcinoma by inducing apoptosis, cell cycle arrest, and suppression of PI3K/AKT/mTOR pathway. 24:853-858

133. Hashemzaei M, Far AD, Yari A, et al (2017) Anticancer and apoptosisinducing effects of quercetin in vitro and in vivo. 819-828. doi: https://doi. org/10.3892/or.2017.5766

134. Kumar A, Manjula M (2015) Anticarcinogenic action of quercetin by downregulation of phosphatidylinositol 3-kinase (PI3K) and protein kinase C (PKC) via induction of p53 in hepatocellular carcinoma (HepG2) cell line. Mol Biol Rep 42:1407-1417. https://doi.org/10.1007/ s11033-015-3921-7

135. Jaouad ZF, Angeles A, Martín J et al (2019) Anti-carcinogenic effects of the flavonoid luteolin. Sci Rep:1-15. https://doi.org/10.1038/s41598-019-47903-0

136. Physiology C (2018) Cyanidin curtails renal cell carcinoma tumorigenesis. 400037:2517-2531. https://doi.org/10.1159/000489658

137. Su S, Yeh T, Lei H (2000) The potential of soybean foods as a chemoprevention approach for human urinary tract cancer 1. 6:230-236

138. Mojic M, Ajdz V, Spasojevic I, Bulatovic M (2013) Membrane fluidity, invasiveness and dynamic phenotype of metastatic prostate cancer cells after treatment with soy isoflavones. 307-314. https://doi.org/10.1007/ s00232-013-9531-1

139. Han B, Li W, Jiang G, et al (2015) Effects of daidzein in regards to cytotoxicity in vitro, apoptosis, reactive oxygen species level, cell cycle arrest and the expression of caspase and Bcl-2 family proteins. 1115-1120. doi: https://doi.org/10.3892/or.2015.4133

140. Zhang H, Hu J, Fu R, et al (2018) Flavonoids inhibit cell proliferation and induce apoptosis and autophagy through downregulation of PI3K $\gamma$ mediated PI3K/AKT/mTOR/p70S6K/ULK signaling pathway in human breast cancer cells. 1-13. doi: https://doi.org/10.1038/s41598-018-29308-7

141. Subhasitanont P, Chokchaichamnankit D, Chiablaem K (2017) Apigenin inhibits growth and induces apoptosis in human cholangiocarcinoma cells. 4361-4371. https://doi.org/10.3892/ol.2017.6705

142. Singh MP, Cho HJ, Kim J, et al (2019) Morin hydrate reverses cisplatin resistance by impairing PARP1/HMGB1-dependent autophagy in hepatocellular carcinoma. 1-16

143. Jaouad ZF, Angeles A, Martín J, et al (2017) Demethylating and antihepatocarcinogenic potential of hesperidin, a natural polyphenol of Citrus juices. 1653-1662 . doi: https://doi.org/10.1002/mc.22621

144. Febriansah R, Sarmoko S, Putri DDP, Nurulita NA $(2014,1691)$ Hesperidin as a preventive resistance agent in MCF-7 breast cancer cells line resistance to doxorubicin. https://doi.org/10.1016/S2221-1691(14)60236-7

145. Du GYU, He SWEl, Zhang LU, et al (2018) Hesperidin exhibits in vitro and in vivo antitumor effects in human osteosarcoma MG-63 cells and xenograft mice models via inhibition of cell migration and invasion, cell cycle arrest and induction of mitochondrial-mediated apoptosis GUANG-YU. 6299-6306 doi: https://doi.org/10.3892/ol.2018.9439

146. Bartoszewski R, Hering A, Marszałł M et al (2014) Mangiferin has an additive effect on the apoptotic properties of hesperidin in Cyclopia sp. Tea Extracts. 9. https://doi.org/10.1371/journal.pone.0092128

\section{Publisher's Note}

Springer Nature remains neutral with regard to jurisdictional claims in published maps and institutional affiliations. 